\title{
The experimental determination of REE partition coefficients in the water-calcite system
}

\author{
Martin Voigt ${ }^{\mathrm{a}, *}$, Vasileios Mavromatis ${ }^{\mathrm{a}}$, Eric H. Oelkers ${ }^{\mathrm{a}, \mathrm{b}}$ \\ ${ }^{a}$ GET/CNRS, 14 avenue Édouard Belin, 31400 Toulouse, France (*correspondence: \\ martin.voigt@get.obs-mip.fr) \\ ${ }^{\mathrm{b}}$ Earth Sciences, UCL, Gower Street, London, United Kingdom
}

\section{Abstract}

To better quantify the behaviour of rare earth elements (REE) in low temperature natural systems, calcite was precipitated from $\mathrm{NaCl}$-bearing aqueous solutions in the presence of $\mathrm{La}$ and $\mathrm{Yb}$ using a constant addition technique at $\mathrm{pH} \sim 6$ and $25{ }^{\circ} \mathrm{C}$ under steady-state conditions. The presence of REE in the fluid significantly slows calcite growth rates. Partition coefficients $\left(D^{\mathrm{REE}}\right)$, determined from analysis of the aqueous solution compositions, range from $10^{2.8}$ at the lowest aqueous La concentration to $10^{1.4}$ at the highest aqueous concentration of $\mathrm{Yb} . D^{\mathrm{REE}}$ was found to correlate with aqueous REE concentrations, as well as with the calcite saturation state. Experimental results, together with previous spectroscopic evidence, suggest the incorporation of $\mathrm{REE}^{3+}$ into the $\mathrm{Ca}^{2+}$ site of calcite while maintaining charge balance by the concurrent incorporation of $\mathrm{Na}^{+}$. The value of the equilibrium constants for the corresponding exchange reaction was determined for $\mathrm{La}, \mathrm{Eu}$ and $\mathrm{Yb}$ by combining our results with previously published experimental data. Subsequently, these constants were used together with a lattice strain model to estimate corresponding values for the other REE. Application of this exchange model suggests that $D^{\mathrm{REE}}$ vary significantly with the composition of natural waters including seawater. Such variations are likely the origin for 
the large differences of $D^{\mathrm{REE}}$ values reported in the literature based on experimental and field evidence.

\section{Keywords}

Rare earth elements; calcite; trace element partitioning; co-precipitation

\section{Introduction}

The rare earth elements (REEs) are of particular interest in geoscience due to their use as chemical tracers of natural processes (e.g., Elderfield et al., 1990; Johannesson et al., 1997; Schnetzler and Philpotts, 1970). As a result of their systematic electron configuration, they exhibit a relatively similar chemical behaviour. Their gradually varying ionic size, however, leads to distinct REE concentration patterns stemming from their aqueous complexation and their varying ability to incorporate into and/or adsorb onto solid phases (e.g., Elderfield, 1988; Elderfield et al., 1990; Köhler et al., 2005; Lipin and McKay, 1989; Schnetzler and Philpotts, 1970). Due to their ability to incorporate REE and their widespread distribution in sedimentary rocks, the REE content of biogenic (e.g., Azmy et al., 2011; Nothdurft et al., 2004; Palmer, 1985; Sholkovitz and Shen, 1995; Webb and Kamber, 2000) and abiogenic carbonates (Parekh et al., 1977) have been used as paleo-proxies for past seawater compositions, its redox state, and its input sources. For example, the REE contents of carbonate minerals have been used to trace fluxes from and to the continents and oceanic crust (Elderfield, 1988). Webb and Kamber (2000) demonstrated that ancient marine REE concentrations can be reconstructed using the REE compositions preserved in sedimentary rocks. Such information could provide insight into the sources of chemical inputs to the oceans over Earth's history. 
The quantification of past ocean water composition using REE patterns in carbonate minerals requires accurate partitioning factors for the aqueous REE - carbonate mineral systems. For this reason, a number of past studies have been aimed at the experimental determination of REE partitioning factors between fluids and co-existing carbonate minerals. Experimentally determined partition coefficients for REEs co-precipitation with calcite have been reported by Terakado and Masuda (1988), Zhong and Mucci (1995), Tanaka and Kawabe (2006) and Toyama and Terakado (2014). Other studies addressed the partitioning behaviour of europium into calcite, as Eu is considered an analogue for long-lived trivalent actinides, which are of interested in nuclear waste disposal (Curti et al., 2005; Lakshtanov and Stipp, 2004; Yeghicheyan, 1996). REE partition coefficients have also been inferred from the composition of reefal microbialities (Webb and Kamber, 2000), reefal Mg-calcites (Scherer and Seitz, 1980), and foraminifers (Palmer, 1985) compared to that of their coexisting ocean waters. While there is a general agreement that REEs are preferentially incorporated into calcite compared to the aqueous solution from which they precipitate, there is considerable disagreement between the magnitudes of this partitioning process (cf. section 2.1). Similarly, there are significant uncertainties about the differences between the partitioning coefficients of individual REEs. This study was motivated to help resolve these discrepancies through the detailed experimental work described below. Most notably, experiments were performed in this study below the hydroxylbastnasite $\left.\left(\operatorname{REE}\left(\mathrm{CO}_{3}\right) \mathrm{OH}\right)\right)$ solubility limit (Voigt et al., 2016) to avoid the interpretative ambiguities of previous studies. By varying aqueous REE concentrations, calcite supersaturation, and precipitation rate, we studied the relationships between calcite precipitation rates and REE partitioning coefficients, as well as effects of changing the concentrations of individual aqueous REEs on calcite growth rates. Results were modelled using thermodynamically based, charge balanced exchange reactions to facilitate their application to a broader range of aqueous solutions. 


\section{Theoretical background}

\subsection{Thermodynamic description of the partitioning of REEs between calcite and co-existing fluids}

The partitioning of REE into calcite is commonly described using the HendersonKracek (1927) partition coefficient $D^{\mathrm{REE}}$, defined as

$$
D^{\mathrm{REE}} \equiv \frac{n_{\mathrm{REE}}^{\text {Calcite }} / n_{\mathrm{Ca}}^{\text {Calcite }}}{n_{\mathrm{REE}}^{\text {Fluid }} / n_{\mathrm{Ca}}^{\text {Fluid }}}
$$

where $n$ stands for the molar amount of the subscripted element in the superscripted phase. Previous experimentally determined partition coefficients were obtained using various fluid compositions and calcite precipitation rates. Such factors, however, likely influence significantly the partitioning behaviour. For example, Terakado and Masuda (1988) suggested that this partitioning is influenced by aqueous REE complexation. Tanaka and Kawabe (2006) used a modified partition coefficient $D_{\omega}^{\mathrm{REE}}$ to address this issue. This modified partition function, taking account of aqueous REE speciation, is defined by:

$$
D_{\omega}^{\mathrm{REE}} \equiv \frac{n_{\mathrm{REE}}^{\text {Calcite }} / n_{\mathrm{Ca}}^{\text {Calcite }}}{n_{\mathrm{REECO}_{3}^{+}}^{\text {Fluid }} / n_{\mathrm{Ca}}^{\text {Fluid }}}
$$

Note the difference between Eqs. (1) and (2) is that the latter is written in terms of the molar amounts of the $\mathrm{REECO}_{3}^{+}$aqueous species, whereas the former is written in terms of the molar amounts of the total aqueous REE.

The partition coefficients $D^{\mathrm{REE}}$ and $D_{\omega}^{\mathrm{REE}}$, as defined in Eqs. (1) and (2) are not consistent with charged balanced exchange reactions, and thus could vary as function of the aqueous phase composition. Due to the charge difference between $\mathrm{Ca}^{2+}$ and $\mathrm{REE}^{3+}$, the formulation of a charge balanced exchange reaction requires knowledge of the reactions dominating this exchange. While there is clear spectroscopic evidence for the incorporation of the REEs into the $\mathrm{Ca}^{2+}$ site in calcite (Elzinga et al., 2002; Withers et al., 2003), different 
reactions for this exchange have been proposed. Some studies suggested that in $\mathrm{NaCl}$ dominated aqueous fluids, charge balance is maintained by co-incorporation of $\mathrm{Na}^{+}$into the calcite structure (Yeghicheyan, 1996; Zhong and Mucci, 1995). An exchange reaction consistent with this observation and the aqueous $\mathrm{REE}^{3+}$ species is given by

$$
\mathrm{Ca}_{2}\left(\mathrm{CO}_{3}\right)_{2}+\mathrm{REE}^{3+}+\mathrm{Na}^{+} \leftrightharpoons \operatorname{NaREE}\left(\mathrm{CO}_{3}\right)_{2}+2 \mathrm{Ca}^{2+}
$$

where $\mathrm{NaREE}\left(\mathrm{CO}_{3}\right)_{2}$ corresponds to a solid Na-REE endmember and $\mathrm{Ca}_{2}\left(\mathrm{CO}_{3}\right)_{2}$ represents the pure calcite endmember. The law of mass action for reaction (3) is given by

$$
K_{D}^{\mathrm{NaREE}\left(\mathrm{CO}_{3}\right)_{2}}=\frac{a_{\mathrm{NaREE}\left(\mathrm{CO}_{3}\right)_{2}}\left(a_{\mathrm{Ca}^{2+}}\right)^{2}}{a_{\mathrm{Ca}_{2}\left(\mathrm{CO}_{3}\right)_{2}} a_{\mathrm{REE}^{3+}} a_{\mathrm{Na}^{+}}} .
$$

where $a_{i}$ denotes the activity of the subscripted component or species. $K_{D}^{\mathrm{NaREE}\left(\mathrm{CO}_{3}\right)_{2}}$ refers to the equilibrium constant of this reaction (see section 2.2 for the choice of standard states). The similar ionic sizes of $\mathrm{Ca}^{2+}$ and $\mathrm{Na}^{+}$favour this reaction, and there is spectroscopic evidence supporting this model (Marques Fernandes et al., 2008; Schmidt, 2009). It should be noted that exchange reactions such as reaction (3), can also be expressed using other aqueous REE species such as $\operatorname{REECO}_{3}^{+}$or $\operatorname{REE}\left(\mathrm{CO}_{3}\right)_{2}^{-}$. Another possible charged balanced REE exchange reaction is

$$
\mathrm{Ca}_{3}\left(\mathrm{CO}_{3}\right)_{3}+2 \mathrm{REE}^{3+} \leftrightharpoons \mathrm{REE}_{2} \mathrm{X}\left(\mathrm{CO}_{3}\right)_{3}+3 \mathrm{Ca}^{2+}
$$

This reaction is based on the presence of a vacancy, $\mathrm{X}$, in the calcite lattice and was proposed by Lakshtanov and Stipp (2004). These authors found this model to be consistent with the results of their co-precipitation experiments. The law of mass action for reaction (5) is given by:

$$
K_{D}^{\mathrm{REE}_{2} \mathrm{X}\left(\mathrm{CO}_{3}\right)_{3}}=\frac{a_{\mathrm{REE}_{2} \mathrm{X}\left(\mathrm{CO}_{3}\right)_{3}}\left(a_{\mathrm{Ca}^{2+}}\right)^{3}}{a_{\mathrm{Ca}_{3}\left(\mathrm{CO}_{3}\right)_{3}}\left(a_{\mathrm{REE}^{3+}}\right)^{2}} .
$$

Curti et al. (2005) tested several solid solution endmembers for Eu incorporation into calcite, including $\mathrm{Eu}_{2}\left(\mathrm{CO}_{3}\right)_{3}, \mathrm{EuOH}\left(\mathrm{CO}_{3}\right), \mathrm{EuNa}\left(\mathrm{CO}_{3}\right)_{2}, \mathrm{EuO}{ }_{x / 2}(\mathrm{OH})_{3-x}, \mathrm{EuH}\left(\mathrm{CO}_{3}\right)_{2}$ and 
$\mathrm{EuO}\left(\mathrm{CO}_{3}\right)_{0.5}$, by applying thermodynamic relationships to experimental data obtained at various conditions. Based on this analysis they concluded that the $\operatorname{EuH}\left(\mathrm{CO}_{3}\right)_{2}$ endmember is the predominant mode of Eu incorporation at low $\mathrm{pH}$, while the $\mathrm{EuO}_{x / 2}(\mathrm{OH})_{3-x}$ dominates Eu incorporation at high $\mathrm{pH}$. These various models are tested against the results of new REE co-precipitation experiments in the presence of $\mathrm{NaCl}$ bearing aqueous solutions as described below.

\subsection{Thermodynamic modelling}

All thermodynamic calculations in this study were performed using the PHREEQC software package (Parkhurst and Appelo, 2013) and the IPhreeqc modules (Charlton and Parkhurst, 2011), coupled with Wolfram Mathematica. The standard state for solid phases and $\mathrm{H}_{2} \mathrm{O}$ is the pure phase, while a hypothetical $1 \mathrm{~mol} / \mathrm{kg}$ aqueous solution referenced to infinite dilution is chosen for unit activity $(a)$ of aqueous species, both at the temperature and pressure of interest. The Livermore National Laboratory aqueous model (Daveler and Wolery, 1992), which uses the extended Debye-Hückel equation (Helgeson, 1969) was used to calculate activity coefficients $(\gamma)$ of aqueous species. The Lawrence Livermore National Laboratory (LLNL) database (Johnson et al., 2000) was used with the modifications and additions explained below. Solubility products $\left(K_{S P}\right)$ of calcite and hydroxylbastnasite were taken from Plummer and Busenberg (1982) and Voigt et al. (2016), respectively. Stability constants for the $\mathrm{CO}_{2}$ solubility and aqueous complexes in the $\mathrm{CO}_{2}-\mathrm{H}_{2} \mathrm{O}-\mathrm{Ca}$ system were taken from Plummer and Busenberg (1982). The stability constants for the REE complexes relevant at the experimental conditions (i.e. $\mathrm{REECO}_{3}^{+}, \mathrm{REE}\left(\mathrm{CO}_{3}\right)_{2}^{-}$and $\mathrm{REEHCO}{ }_{3}^{2+}$ ) were taken from Luo and Byrne (2004). The activities of the solid components, such as $a_{\mathrm{NaREE}\left(\mathrm{CO}_{3}\right)_{2}}$, are calculated assuming ideal solid solutions (i.e. the activity coefficients $\gamma$ for solid components are equal to one, cf. Appendix A). 


\section{Methods}

\subsection{Experimental design}

The co-precipitation of REE with calcite was conducted using the "constant addition technique", inspired by experiments reported in previous studies (Gautier et al., 2014; Mavromatis et al., 2013, 2015, 2017; Tesoriero and Pankow, 1996; Zhong and Mucci, 1995). This technique allows the co-precipitation of calcite with trace elements at selected rates and at constant reactive fluid compositions. Precipitation took place in $1 \mathrm{~L}$ polypropylene (PP) reactors, which were placed on an orbital shaker (Fig. 1). The fluid in these reactors was held at a constant temperature of $25 \pm 0.5{ }^{\circ} \mathrm{C}$ using purpose-built heating coils connected to a thermostatically controlled water bath. Preliminary experiments showed that mixing the calcite-fluid mixtures using orbital shaking at $250 \mathrm{rpm}$ keeps the calcite powder in suspension while avoiding precipitation on the reactor walls.

At the beginning of each experiment, the reactors were filled with 80 to $400 \mathrm{~g}$ of an aqueous solution containing 0.1 or $0.15 \mathrm{~mol} / \mathrm{kg} \mathrm{NaCl}$, which was in equilibrium with calcite at the experimental conditions. To achieve calcite equilibrium, aqueous $\mathrm{NaCl}$ (VWR AnalR Normapur) solutions were equilibrated with $\sim 4 \mathrm{~g}$ of Merck EMSURE calcite powder (having diameters of approximately 3-15 $\mu \mathrm{m}$ ) while continuously bubbling pure $\mathrm{CO}_{2}$ (>99.9\% purity, supplied by Air Products) through this fluid at ambient pressure for at least $5 \mathrm{~h}$ at $25{ }^{\circ} \mathrm{C}$. The $\mathrm{CO}_{2}$ was first bubbled into an Erlenmeyer flask filled with ultrapure water to saturate the gas with water, and then into the reactor fluid. The saturation state of the resulting reactor fluid was confirmed by $\mathrm{pH}$ measurements indicating that steady state $\mathrm{pH}$ was attained. Moreover, the measured $\mathrm{pH}$ values were consistent with PHREEQC predictions in equilibrium with calcite under the experimental conditions. This solution was filtered through a $0.22 \mu \mathrm{m}$ polyethersulfone (PES) membrane prior to its use in the experiments. 
All experiments were run in equilibrium with a $\mathrm{CO}_{2}$ partial pressure $\left(p \mathrm{CO}_{2}\right)$ of $1 \mathrm{~atm}$, maintained by bubbling pure $\mathrm{CO}_{2}$ in the same way as in the calcite saturation runs prior to the experiments. This resulting $p \mathrm{CO}_{2}$ leads to a $\mathrm{pH}$ of $\sim 6.0$ to 6.4 during the calcite precipitation experiments, allowing the use of relatively high REE concentrations $\left(c_{\mathrm{REE}}\right)$ without risking the precipitation of pure REE-carbonate mineral phases.

From $\sim 0.75$ to $2 \mathrm{~g}$ of calcite powder, identical to the material used in the saturation runs, was initially placed into the reactor to act as seed material for the precipitation together with the calcite saturated fluid. The initial synthetic calcite seed crystals exhibit a typical rhombohedral shape with a diameter of approximately 3-15 $\mu \mathrm{m}$ and clean surfaces. Each coprecipitation experiment was initiated by pumping two aqueous solutions, one containing $\mathrm{CaCl}_{2}$ (dihydrate, Merck EMSURE), together with the desired amount of REEs, and the other containing $\mathrm{Na}_{2} \mathrm{CO}_{3}$ (Merck EMSURE), into the reactor using a peristaltic pump. Solutions were pumped at equal flow rates ranging from approximately 8.5 to $45 \mathrm{~g} / \mathrm{day}$; these fluid flow rates were verified by repeated weighing of the inlet fluid reservoirs during each experiment. The molar concentrations of $\mathrm{CaCl}_{2}$ and $\mathrm{Na}_{2} \mathrm{CO}_{3}$ pumped into the reactor were equal and ranged from $\sim 70$ to $150 \mathrm{mmol} / \mathrm{kg}$, leading to calcite supersaturation in the reactor fluid and inducing calcite precipitation at constant reactive fluid composition after an initial adjustment period (c.f. section 4.2 and Appendix B). The $\mathrm{NaCl}$ concentration of the inlet fluids was adjusted for each experiment such that the ionic strength equalled that of the original reactive fluid. The REEs were added to the $\mathrm{CaCl}_{2}$ inlet solution using $1000 \mathrm{mg} / \mathrm{L} \mathrm{REE}$ standard solutions prepared in an aqueous $\mathrm{HNO}_{3}$-matrix (SCP Science PlasmaCAL or SPEX CertiPrep). The $\mathrm{HNO}_{3}$ added to the inlet solutions via these standards was neutralized by addition of the required amount of $\mathrm{NaOH}$. One light and one heavy REE, i.e. lanthanum and ytterbium, were used in this study to assess the effect of the changing elemental properties such as the ionic radius on the partitioning behaviour. Experiments were performed using 
individual REEs and a combination of these two instead of using all REEs at the same time (1) in order to study the partitioning behaviour of the individual REEs without the potential interference from other REEs and (2) to keep the aqueous solutions undersaturated with respect to REE-carbonate phases. The aqueous solution in the reactor was sampled regularly using a pipette and subsequently filtered with a $0.22 \mu \mathrm{m}$ PES membrane syringe filter. To minimize the potential loss of calcite from the reactor, mixing was stopped $\sim 1$ min before sampling, allowing the calcite powder to settle. One fluid sub-sample was immediately acidified with bi-distilled $\mathrm{HNO}_{3}$ for later analysis of the REE and $\mathrm{Ca}$ concentrations, while a non-acidified sub-sample was kept for alkalinity measurements. Sampling also involved the in situ measurement of $\mathrm{pH}$. The experiments were terminated after 3 to 13 days (depending on the time required to achieve steady-state, cf. section 4.2) and the suspensions in the reactors were filtered through a $0.22 \mu \mathrm{m}$ mixed cellulose ester membranes to recover the solids, which were rinsed with ultrapure water and ethanol after filtration and dried at room temperature. The REE contents of the precipitated calcite were calculated in this study from the changes in the composition of the reactive fluids and mass balance constraints. Details on the calculation of the partition coefficients and calcite precipitation rates from the fluid compositions are provided in Appendix A.

\subsection{Analytical methods}

All $\mathrm{pH}$ measurements were performed in situ during the experiments, because of the high $p \mathrm{CO}_{2}$ in the reactor, using an Orion 8103NUWP ROSS Ultra $\mathrm{pH}$ electrode. This electrode was rinsed with dilute $\mathrm{HCl}$ and ultrapure water before and after each use. The reactor was shaken at $\sim 50 \mathrm{rpm}$ until a stable potential was attained, after which mixing was stopped (to avoid the build-up of stirring potentials) and the potential was recorded while $\mathrm{CO}_{2}$ was continuously bubbled through the reactor solution. The $\mathrm{pH}$ electrode was calibrated using Fluka 4.0, 6.9 and 9.2 NIST traceable pH buffer solutions before each use at $25{ }^{\circ} \mathrm{C}$. The 
precision of these measurements is estimated to be $\pm 0.03 \mathrm{pH}$ units based on replicate analyses of buffers and samples. Alkalinity of inlet and sampled fluids was determined by titration using a Schott Titroline alpha plus titrator, usually within $24 \mathrm{~h}$ after sampling to avoid calcite precipitation in the sample vial. Atomic absorption spectrometry (AAS) was used to determine the calcium concentrations in all aqueous solutions. Prior to AAS analysis on the Perkin Elmer AAnalyst 400, the samples were diluted using $0.01 \mathrm{~mol} / \mathrm{kg} \mathrm{HNO}_{3}$ and a small amount of lanthanum was added to avoid matrix effects. The detection limit of this method is approximately $2 \times 10^{-7} \mathrm{~mol} / \mathrm{kg}$ and their reproducibility was approximately $1 \%$ as indicated by replicate measurements. The standards, ranging from $10^{-5}$ to $10^{-4} \mathrm{~mol} / \mathrm{kg} \mathrm{Ca}$, were prepared from an aqueous $1000 \mathrm{mg} / \mathrm{L}$ Merck Certipur Ca solution. The REE contents of inlet and sampled fluids were measured by Inductively Coupled Plasma Mass Spectrometry (ICP-MS) using a Thermo Fisher Element XR spectrometer. The samples were diluted by a factor of 60 with bi-distilled $0.37 \mathrm{~mol} / \mathrm{kg} \mathrm{HNO}_{3}$ prior to analysis to reduce matrix effects, resulting in a total solute concentration of approximately $100 \mathrm{ppm}$. Quantification limits, determined by analysis of blanks that were subjected to the same experimental and analytical procedures as actual samples, are approximately $5 \times 10^{-10} \mathrm{~mol} / \mathrm{kg}$ before dilution. Calcium concentrations were also determined by ICP-MS, and are in close agreement with the more precise AAS analyses considering the uncertainties. The $\mathrm{CO}_{2}$ partial pressure $\left(p \mathrm{CO}_{2}\right)$ in the reactors was not measured directly, it was calculated from the measured $\mathrm{pH}$, alkalinity and aqueous matrix composition with PHREEQC. The calculated $p \mathrm{CO}_{2}$ ranged from $\sim 0.91$ to $1.02 \mathrm{~atm}$, which is in close agreement with the $p \mathrm{CO}_{2}$ of 0.97 atm calculated for a $0.1 \mathrm{M} \mathrm{NaCl}$ aqueous solution in equilibrium with calcite and pure $\mathrm{CO}_{2}$. Initial calcite grains and solids recovered from the reactors after the experiments were analysed by Scanning Electron Microscopy (SEM) using a Jeol JSM 6360LV, by powder X-ray diffraction (XRD) together with a Bruker D8 Phaser with a Cu source and a X-ray wavelength of $0.154060 \mathrm{~nm}$ (analyses 
were performed within approximately 1 month after the end of the experiments), and their specific surface area was determined using the BET technique (Brunauer et al., 1938) using krypton and 11 measured adsorption points.

\subsection{Uncertainties and statistical criteria}

The uncertainties of quantities reported in this study, designated by the \pm symbol, refer to one standard deviation $(\sigma)$. Where possible, the propagation of these uncertainties was performed using common algebraic relationships. For highly non-linear functions (e.g. PHREEQC calculations), propagation of uncertainties was performed using Monte Carlo type simulations. In the case of model fits, an effective variance technique (Orear, 1982) was used, which gives the parameter estimates and their standard errors based on the uncertainties of all input parameters. The reduced chi-squared statistic $\left(\chi_{\text {red }}^{2}\right.$, the sum of squared errors, weighted by the variance of the observations and divided by the number of degrees of freedom) is given for model fits as a measure of the goodness of fit accounting for the uncertainties in the observations. A $\chi_{\text {red }}^{2}$ close to unity indicates that the squared errors are consistent with the

uncertainties while $\chi_{\text {red }}^{2} \gg 1$ suggests a poor model fit (Bevington and Robinson, 2003). Correlations among different parameters are examined using Spearman's rank correlation coefficient $\rho$, which describes how well the relationship between two parameters can be described by a monotonic function $(\rho=1$ or $\rho=-1$ for perfect positive or inverse correlations, and $\rho=0$ for no correlation).

\section{Results}

\subsection{Characteristics of the solids}

Scanning electron microscope (SEM) images of the initial calcite seeds and the calcite recovered from representative experiments are shown in Fig. 2. Examination of the solids 
recovered from the reactors after the experiments suggests that minor crystal aggregation occurred during the experiments, which is consistent with numerous previous calcite precipitation studies (e.g., Andreassen, 2001; Collier and Hounslow, 1999; Tai and Chen, 1995; Wachi and Jones, 1991). Furthermore, the SEM images show that the surface roughness increased during crystal growth, which is also reflected in the higher BET specific surface areas of the products with a mean value of $0.46 \mathrm{~m}^{2} / \mathrm{g}$ (see Table 1) compared to the initial value of $0.24 \mathrm{~m}^{2} / \mathrm{g}$. SEM observations did not reveal any difference in the morphology of the precipitated materials as a function of fluid REE concentration, precipitation rate, or the identity of the REE in the aqueous phase.

The XRD patterns of the recovered solids, shown in Supplementary Fig. S1, are similar to that of the original seed material, and no evidence of aragonite or hydroxylbastnasite was detected (within the detection limit of $\sim 1 \mathrm{wt} \%$ ). According to thermodynamic calculations, the mineral hydroxylbastnasite $(\mathrm{REEOHCO} 3)$ is the REE mineral with the lowest solubility at the experimental conditions. Although the solubility product of hydroxylbastnasite has only been reported for the La- and $\mathrm{Nd}$ - endmembers $\left(\log \left(\mathrm{K}_{\mathrm{SP}}\right)\right.$ of $-23.8 \pm 0.1$ and $-24.1 \pm 0.3$, respectively (Voigt et al., 2016)), the solubilities of heavy-REE minerals are likely to be systematically higher (Voigt et al., 2016). Thermodynamic calculations suggest that the reactive aqueous solutions are undersaturated with respect to hydroxylbastnasite at La concentrations below approximately $2 \times 10^{-8} \mathrm{~mol} / \mathrm{kg}$, which is the case for all of our reactive fluids except for CP16 (see Table 2), which shows slightly higher La concentrations at steady state, further suggesting that no pure REE carbonate phases precipitated during the experiments. The calculated values of $X_{\mathrm{La}}$ and $X_{\mathrm{Yb}}$, the cation molar fractions of $\mathrm{La}$ and $\mathrm{Yb}$ in the precipitated calcite, for our experiments are listed in Table 2 and range from approximately $4 \times 10^{-5}$ to $1.4 \times 10^{-4}$, indicating that that less than one $\mathrm{REE}^{3+}$ ion is incorporated per $\sim 7000 \mathrm{Ca}^{2+}$ ions in the calcite. This is consistent 
with the experimentally determined upper limit for $\mathrm{Eu}^{3+}$ uptake of Stipp et al. (2006), which suggests that one $\mathrm{Eu}^{3+}$ can be incorporated for every $\sim 900 \mathrm{Ca}^{2+}$ ions.

\subsection{Attainment of steady-state reactive fluid compositions and retrieved precipitation rates}

The term steady-state in this study is defined by reactive fluids that exhibited no change in $\mathrm{pH}$, calcium concentration, and alkalinity within analytical uncertainty for at least 48 hours during an experiment. An example of the attainment of steady state is shown in Fig. 3. It can also be seen that the fluid phase REE concentration in this example was relatively constant after 16 hours. To estimate the uncertainty associated with the variation of these parameters, 3-5 reactive fluid samples were taken during each experiment after steady-state was attained, and the mean values and standard deviations of these reactive fluid compositions are reported in Table 1. It should be noted that deviations from steady-state occur due to the slow increase of the surface area, $A$, of the solids present during each experiment; this variation in surface area is accounted for in the calculation of the calcite precipitation rates $\mathcal{R}$ through Eqs. (A.7) and (A.8) in Appendix A.

Comparison of the calcite precipitation rates calculated using either aqueous calcium concentrations $\mathcal{R}_{t}^{\mathrm{Ca}}$ or alkalinity measurements $\mathcal{R}_{t}^{\text {Alk }}$ show an excellent agreement, and the mean value of both, averaged over the individual fluid samples taken during steady-state for each experiment, is provided in Table 2. The calculated precipitation rates ranged from $10^{-7.0}$ to $10^{-8.3} \mathrm{~mol} / \mathrm{m}^{2} / \mathrm{s}$, spanning approximately one order of magnitude (Table 2).

\subsection{REE partition coefficients between aqueous solution and calcite}

The absolute values of the Henderson-Kracek partition coefficient $\left(D^{\mathrm{REE}}\right)$, determined from Eq. (1) together with measured fluid compositions are reported in Table 2. These values range from $10^{2.8}$ at the lowest aqueous La concentration to $10^{1.4}$ for the highest aqueous $\mathrm{Yb}$ 
concentrations. A strong negative correlation (correlation coefficient of $\rho=-0.86$ ) is evident between the reactive fluid REE concentration and $D^{\mathrm{REE}}$ as can be seen in Fig. $4 \mathrm{a} . D^{\mathrm{La}}$ are significantly higher than $D^{\mathrm{Yb}}$ at high aqueous REE concentrations, but both partition coefficients are of similar magnitude at lower concentrations. This partition coefficient is also negatively correlated with the calcite saturation state $\Omega$ (defined as $\Omega=\left(a_{\mathrm{Ca}^{2+}} a_{\mathrm{CO}_{3}^{2-}}\right) /$ $\left.\left(K_{S P}^{\text {Calcite }}\right)\right)$ in our dataset $(\rho=-0.84)$, as shown in Fig. 4 b. This observation may be due to the inhibition of calcite growth rates by the presence of aqueous REE (see section 5.4), leading to higher supersaturation with respect to calcite in the experiments with increasing REE concentration. Due to the magnitude of this effect, it dominates $\Omega$ in our dataset, leading to the covariation of $c_{\mathrm{REE}}$ and $\Omega(\rho=0.90)$.

\section{Discussion}

\subsection{REEs exchange reactions in the aqueous fluid and calcite system}

The partitioning of the REEs between aqueous solutions and calcite as a function of the precipitation rate and REE concentration cannot be described by a single partition coefficient $\left(D^{\mathrm{REE}}\right)$. Therefore, we adopt thermodynamic models to calculate the equilibrium distribution coefficients $\left(K_{D}\right)$ for the different possible exchange mechanisms (see section 2.1). Statistical criteria can then be used to infer the model most consistent with the observations. Resulting values for the exchange reactions involving the $\operatorname{NaREE}\left(\mathrm{CO}_{3}\right)_{2}$, $\mathrm{REE}_{2} \mathrm{X}\left(\mathrm{CO}_{3}\right)_{3}$ and $\mathrm{H}(\mathrm{REE})\left(\mathrm{CO}_{3}\right)_{2}$ solid endmembers are shown in Table 3. It can be seen that the standard deviations for $K_{D}^{\mathrm{REE}_{2} \mathrm{X}\left(\mathrm{CO}_{3}\right)_{3}}$ are significantly higher than that of the other two exchange models, indicating a worse fit of this exchange model to the experimental observations. The $K_{D}$ of the other two examined exchange reactions have similar standard errors, but based on spectroscopic evidence (Marques Fernandes et al., 2008; Schmidt, 2009) and previous REE co-precipitation experiments showing a correlation between $D^{\mathrm{Na}}$ and 
aqueous REE concentrations (Yeghicheyan, 1996; Zhong and Mucci, 1995) reaction (3) was adopted to describe our experimental observations. Note also that the similar sizes of the $\mathrm{Ca}^{2+}$ and $\mathrm{Na}^{+}$favour the incorporation of $\mathrm{Na}$ into calcite, as the energy required for the lattice deformation during this process is related to the size difference between the host lattice site and the foreign ion (Blundy and Wood, 1994). This approach is similar to that of Curti et al. (2005). These authors assumed, however, that their experiments were in thermodynamic equilibrium with the REE bearing solid endmember, whereas we assume equilibrium only with the exchange reactions described in section 2.1 . While this is only a small conceptual difference, our $K_{D}$ are more closely related to the classic partition coefficients $D^{\mathrm{REE}}$ which take into account the aqueous $\mathrm{Ca}$ concentrations in addition to the concentrations of REEs in the fluid and solid phases. It should be emphasized, however, that as fluid compositions change other exchange reactions may dominate the incorporation of REEs in calcite (e.g. the incorporation as $\operatorname{NaREE}\left(\mathrm{CO}_{3}\right)_{2}$ is not possible in the absence of $\mathrm{Na}$ ), such that no single exchange model is likely valid at all conditions.

As noted by Curti et al. (2005), the results of Lakshtanov and Stipp (2004), which were obtained for Eu under similar conditions as our experimental results, are incompatible with the presence of a vacancy in calcite, but consistent with exchange reactions involving either $\operatorname{NaREE}\left(\mathrm{CO}_{3}\right)_{2}$ or $\mathrm{H}(\mathrm{REE})\left(\mathrm{CO}_{3}\right)_{2}$. The $K_{D}$ for these two models fit to the Eucoprecipitation data of Lakshtanov and Stipp (2004) are also provided in Table 3, suggesting a similar goodness for both model fits.

Due to REE inhibition of calcite growth rates, our datasets exhibit a high degree of covariation between aqueous REE concentrations and fluid supersaturation with respect to calcite. As REE strongly inhibit calcite growth rates, it is not possible to distinguish how partition coefficients depend on one or the other without knowledge of the exchange reaction. In principle, experiments at high $\Omega$ but low $c_{\mathrm{REE}}$ could resolve such ambiguities, however, the 
difficulty of achieving sufficiently high saturation states at low $c_{\text {REE }}$ without significantly increasing the ionic strength and calcite precipitation rates to levels where precipitation kinetics likely affect the partitioning behaviour prohibited this approach in our study. However, assuming the validity of the exchange reaction involving $\operatorname{NaREE}\left(\mathrm{CO}_{3}\right)_{2}$, the behaviour of $D^{\mathrm{REE}}$ as function of fluid composition can be predicted using the relationship:

$$
\begin{aligned}
& D^{\mathrm{REE}}=K_{D}^{\mathrm{NaREE}\left(\mathrm{CO}_{3}\right)_{2}} \cdot \frac{a_{\mathrm{Na}^{+}} c_{\mathrm{Ca}}}{2\left(a_{\mathrm{Ca}^{2}}\right)^{2}} . \\
& \frac{\gamma_{\mathrm{REECO}}^{+} \gamma_{\mathrm{REE}\left(\mathrm{CO}_{3}\right)_{2}^{-}} \gamma_{\mathrm{REEHCO}}^{2+} \gamma_{\mathrm{REE}^{3+}} K_{2}}{\left(\begin{array}{c}
a_{\mathrm{CO}_{3}^{2-}} \gamma_{\mathrm{REEHCO}_{3}^{2+}} \gamma_{\mathrm{REE}\left(\mathrm{CO}_{3}\right)_{2}^{-}} \gamma_{\mathrm{REE}^{3+}} K_{2} K_{\mathrm{REECO}_{3}^{+}} \\
+\gamma_{\mathrm{REECO}_{3}^{+}} \gamma_{\mathrm{REEHCO}_{3}^{2+}} K_{2}\left(\gamma_{\mathrm{REE}\left(\mathrm{CO}_{3}\right)_{2}}+\left(a_{\mathrm{CO}_{3}^{2-}}\right)^{2} \gamma_{\mathrm{REE}^{3+}}+K_{\mathrm{REE}\left(\mathrm{CO}_{3}\right)_{2}^{-}}\right) \\
+a_{\mathrm{CO}_{3}^{2-}} a_{\mathrm{H}^{+}} \gamma_{\mathrm{REECO}_{3}^{+}} \gamma_{\mathrm{REE}\left(\mathrm{CO}_{3}\right)_{2}^{-}} \gamma_{\mathrm{REE}^{3+}} K_{\mathrm{REEHCO}_{3}^{2+}}
\end{array}\right)}
\end{aligned}
$$

where $\gamma_{i}$ represents the activity coefficients of the subscripted aqueous species, which are derived from combining Eqs. (1) and (4) with thermodynamic activity-concentrations relationships (cf. Appendix C). The form of Eq. (7) suggests that $D^{\mathrm{REE}}$ is close to independent of the REE content of the aqueous solution (assuming only trace quantities are present), if all other compositional parameters remain constant. This implies that the other compositional parameters in the equation, namely the aqueous calcium, $\mathrm{CO}_{3}^{2-}, \mathrm{H}^{+}$and $\mathrm{Na}^{+}$concentrations, have a major influence on $D^{\mathrm{REE}}$. Due to analytical restrictions and to keep the ionic strength relatively constant, experiments at significantly higher aqueous $\mathrm{Na}^{+}$concentrations were not possible in this study, and increasing fluid $\mathrm{Ca}^{2+}$ without changing $c_{\text {REE }}$ will influence $D^{\mathrm{REE}}$ through precipitation kinetic effects as described above. Since sodium concentrations and $\mathrm{pH}$ are relatively constant in our experiments, the aqueous calcium and $\mathrm{CO}_{3}^{2-}$ concentrations, and therefore $\Omega$, are likely the primary causes of the variability in the partition coefficient $D^{\text {REE }}$ observed in our experiments. 


\subsection{Differences between the partitioning behaviour of the individual REEs}

It can be seen in Table 3 that the $K_{D}^{\mathrm{NaREE}\left(\mathrm{CO}_{3}\right)_{2}}$ obtained from the regression of experimental data vary among $\mathrm{La}, \mathrm{Yb}$ and Eu. As shown by Blundy and Wood (1994), lattice strain induced in the solid by differences in the ionic size of foreign ions and their host site has a major influence on partition coefficients. Adopting their model the following expression is obtained describing the dependence of the REE partition coefficients on the size difference between the radius of the host lattice site $\left(r_{0}\right)$ and the foreign ions $\left(r_{\mathrm{REE}}, r_{\mathrm{Na}}\right)$, as well as the elastic response of that site $(E)$ :

$$
\begin{aligned}
& K_{D}^{\mathrm{NaREE}\left(\mathrm{CO}_{3}\right)_{2}} \\
& =K_{D}^{0} \exp \left(\frac{-4 \pi N_{A}(2 E)\left(\frac{1}{2} r_{0}^{3+}\left(r_{\mathrm{REE}}+r_{\mathrm{Na}}-2 r_{0}\right)^{2}+\frac{1}{3}\left(r_{\mathrm{REE}}+r_{\mathrm{Na}}-2 r_{0}\right)^{3}\right)}{R T}\right)
\end{aligned}
$$

where $R$ stands for the ideal gas constant, $N_{A}$ designates the Avogadro constant and $T$ refers to the temperature in kelvin. Because of the charge-balanced exchange of two $\mathrm{Ca}^{2+}$ ions for $\mathrm{Na}^{+}+\mathrm{REE}^{3+}$ in the $K_{D}^{\mathrm{NaREE}\left(\mathrm{CO}_{3}\right)_{2}}$ model, the sum of the radii differences between $r_{\mathrm{REE}}, r_{\mathrm{Na}}$ and $r_{0}$ have to be considered, and the factor of 2 for the elastic response is introduced to facilitate comparison with the elastic modulus based on a single $\mathrm{CaCO}_{3}$ unit. In this model, $K_{D}^{0}$ corresponds to the strain-compensated partition coefficient for an ion with radius $r_{0}$. The curve shown in Fig. 5 was obtained using the $K_{D}^{\mathrm{NaREE}\left(\mathrm{CO}_{3}\right)_{2}}$ values listed in Table 3 (an uncertainty of 0.1 was assigned to $K_{D}^{\mathrm{NaEu}\left(\mathrm{CO}_{3}\right)_{2}}$ to account for experimental and analytical interlaboratory differences) using the effective ionic radii of octahedrally coordinated REE reported by Shannon (1976). The best fit parameters are $r_{0}=(111.7 \pm 0.1) \mathrm{pm}, E=$ $(81 \pm 5) \mathrm{GPa}$ and $\log K_{D}^{0}=(3.84 \pm 0.04)$. The value of $r_{0}$ is slightly smaller than the effective ionic radius of octahedrally coordinated $\mathrm{Ca}^{2+}, 112 \mathrm{pm}$, which is consistent with the observations of Blundy and Wood (2003), who noted that $r_{0}$ decreases with the increasing 
charge of the foreign ion. Furthermore, the site elastic modulus $(E)$ retrieved here is in good agreement with the aggregate elastic modulus for calcite of approximately $76 \mathrm{GPa}$ (Chen et al., 2001), validating our lattice strain model parameters.

\subsection{Variation of REE partitioning as function of precipitation rate}

No correlation between the precipitation rate and $D^{\mathrm{REE}}$ or $K_{D}^{\mathrm{NaREE}\left(\mathrm{CO}_{3}\right)_{2}}$ is evident in our experimental dataset (Fig. 6). The variability in $D^{\mathrm{REE}}$ can be largely attributed to the fact that $D^{\mathrm{REE}}$ is a strong function of aqueous fluid composition (cf. section 5.1). While Zhong and Mucci (1995) and Lakshtanov and Stipp (2004) did not detect a correlation between the calcite precipitation rate and the partition coefficient for rates ranging from approximately $\log \left(\mathcal{R} /\left(\mathrm{mol} / \mathrm{m}^{2} / \mathrm{s}\right)\right)=-9.4$ to -6.7 , Yeghicheyan (1996) observed decreasing $D^{\mathrm{Eu}}$ with increasing growth rates. The high precipitation rates observed by Yeghicheyan (1996), ranging from $\log \left(\mathcal{R} /\left(\mathrm{mol} / \mathrm{m}^{2} / \mathrm{s}\right)\right)=-7.2$ up to -4.9 , could explain the relationship seen in their data, as the precipitation kinetics could influence REE partitioning at faster growth rates. Since the precipitation rates of authigenic marine limestone are usually below $10^{-7}$ $\mathrm{mol} / \mathrm{m}^{2} / \mathrm{s}$ (Karaca et al., 2010; Luff et al., 2005), the independence of the partitioning behaviour seen in our experiments and in data of Zhong and Mucci (1995) and Lakshtanov and Stipp (2004) is likely to be a closer representation of the natural conditions during marine authigenic calcite formation. Molar growth rates of marine biogenic calcite can be estimated from linear growth rates: Taking data of Böhm et al. (1996) and Fallon et al. (2003), the range of approximately 0.5 to $1.5 \mathrm{~mm} /$ year translates to $\sim 10^{-7.1}$ to $10^{-6.6} \mathrm{~mol} / \mathrm{m}^{2} / \mathrm{s}$ assuming that the surface area available for growth is twice that of the macroscopic living surface (Gussone et al., 2005). These estimates are at the upper end of the values used in this study, suggesting that growth rate effects on REE partitioning could play a role in the case of fast biogenic calcite precipitation. 
The observation that the partitioning is independent from the precipitation rate for growth rates below $\sim 10^{-7} \mathrm{~mol} / \mathrm{m}^{2} / \mathrm{s}$ is consistent with findings for $\mathrm{Sr}$ and $\mathrm{Ba}$ co-precipitation with calcite (Gabitov et al., 2014; Lorens, 1981; Tesoriero and Pankow, 1996) indicating that kinetic effects are only present at growth rates above $\sim 10^{-6.5} \mathrm{~mol} / \mathrm{m}^{2} / \mathrm{s}$ for these elements. This is conceptually consistent with kinetic models which predict that equilibrium precipitation is approached below a threshold where processes such as growth entrapment do not occur (DePaolo, 2011; Thien et al., 2014; Watson, 2004). However, correlations between precipitation rates and partitioning of cations is observable for rates as low as $\sim 10^{-8}$ for $\mathrm{Mg}$ and Ni (Lakshtanov and Stipp, 2007; Mavromatis et al., 2013), indicating that this observation is not generally valid for trace cation incorporation into calcite.

\subsection{Inhibition of calcite growth by aqueous REE}

To quantify the effect of aqueous REE concentration on calcite growth, we adopt the empirical rate law (Morse, 1978)

$$
\mathcal{R}_{0}=k(\Omega-1)^{n}
$$

where $\mathcal{R}_{0}$ stands for the calcite precipitation rate in absence of REEs, $n$ designates an empirical reaction order and $k$ represents a rate constant. Regression of the rates measured in the absence of REEs in this study are found to be consistent with $n=0.95 \pm 0.68$ and $\log \left(k /\left(\mathrm{mol} / \mathrm{m}^{2} / \mathrm{s}\right)\right)=-6.38 \pm 0.52($ see Fig. 7)

Assuming that an exchange reaction such as (3) is the predominant process, aqueous $\mathrm{Ca}^{2+}$ ions can compete with aqueous REEs for adsorption onto the calcite surface sites during its growth. This suggests a competitive Langmuir adsorption mechanism, comparable to that used to describe the incorporation of $\mathrm{Mg}$ and $\mathrm{Mn}$ into calcite (Dromgoole and Walter, 1990a; Lin and Singer, 2009). Similar to the derivation of Lin and Singer (2009), by assuming a 
correlation between the calcite growth rate and the concentration of surface sites occupied by $\mathrm{Ca}^{2+}$, one obtains

$$
\frac{\mathcal{R}_{0}-\mathcal{R}}{\mathcal{R}}=k^{*}\left(\frac{\sum c_{\mathrm{REE}}}{a_{\mathrm{Ca}^{2+}}}\right)^{b}
$$

where $k^{*}$ and $b$ represent empirical constants. The total aqueous REE concentration $c_{\text {REE }}$ is used in this expression as it is not known which aqueous REE complexes dominate the rate controlling effect. Note a linear correlation with $b=1$ is inconsistent with the growth inhibition seen in our experiments. A best fit for this model to our experimental data yields $\log k^{*}=8.6 \pm 1.5$ and $b=1.2 \pm 0.26$ with a $\chi_{\text {red }}^{2}$ of 0.24 (see Fig. 8). The strong effect of aqueous REE on calcite precipitation rates even at the low aqueous REE concentrations present in our experiments is consistent with findings of Zhong and Mucci (1995), who observed an inhibitory effect of aqueous REE concentrations below $1 \mu \mathrm{mol} / \mathrm{kg}$. Similarly, Akagi and Kono (1995) reported an inhibition of calcite precipitation rates at molar REE/Ca ratios of $10^{-4}$. The magnitude of the inhibition caused by the presence of aqueous REEs is much higher compared to other elements: Lin and Singer (2009) found $\log k^{*}=0.5$ for $\mathrm{Mg}$, and data of Dromgoole and Walter (1990a) are consistent with $\log k^{*} \approx 2.7$ for $\mathrm{Mn}$. Consideration of the partition coefficients of these elements, which are $\log D^{\mathrm{Mg}} \approx-1.7$ (Mavromatis et al., 2013) and $\log D^{\mathrm{Mn}} \approx 1$ (Dromgoole and Walter, 1990b), respectively, suggests a relationship between the inhibitory effect on calcite precipitation rates and the magnitude of trace element incorporation. This is consistent with the microscopic crystal growth model proposed by Nielsen et al. (2013), where the incorporation of trace elements into minerals can lead to these ions acting as active growth site (kink) blockers, which was also proposed for the growth of calcite in the presence of $\mathrm{Sr}^{2+}$ (Wasylenki et al., 2005). 


\subsection{REE partitioning in seawater}

A major application of REE fractionation between calcite and aqueous fluids is in marine environments. For this purpose, the results of this study can be related to seawater compositions using the $\operatorname{NaREE}\left(\mathrm{CO}_{3}\right)_{2}$ model described above. Note this application requires that this exchange reaction dominates at seawater conditions as it does at $\mathrm{pH} 6$ and $p \mathrm{CO}_{2}$ of 1 atm. This assumption is supported by spectroscopic evidence from experiments at $\mathrm{pH} 8$ (Marques Fernandes et al., 2008; Schmidt, 2009) and the observation of a correlation between $D^{\mathrm{Na}}$ and aqueous REE concentrations by Zhong and Mucci (1995); each of these observations is consistent with the incorporation of REEs from seawater into calcite as $\operatorname{NaREE}\left(\mathrm{CO}_{3}\right)_{2}$. Relating our experimental data, obtained at $\mathrm{pH} \sim 6$, to marine conditions has the advantage of avoiding the solubility minimum of phases such as hydroxylbastnasite at $\mathrm{pH} 8.2$ (Voigt et al., 2016). The low solubility restricts the performance of non-ambiguous experiments to extremely low aqueous REE concentrations, leading to analytical difficulties at such conditions in experimental studies.

Using an extended version of Eq. (7), together with the seawater composition of Millero et al. (2008) and $K_{D}^{\mathrm{NaREE}\left(\mathrm{CO}_{3}\right)_{2}}$ from the best fit to the lattice strain model described above (Eq. (8)), the partition coefficients for seawater were obtained; these values are shown in Fig. 9 and Table 4. Note this extended equation (7) takes account of the REE complexes present in minor amounts in seawater $\left(\mathrm{REECl}^{+}, \mathrm{REESO}_{4}^{+}\right.$and $\left.\mathrm{REEOH}^{2+}\right)$ as estimated using stability constants at zero ionic strength from Luo and Byrne (2001), Schijf and Byrne (2004) and Klungness and Byrne (2000), respectively. Furthermore as noted in section 2.1, the exchange reaction based on the formation of $\operatorname{NaREE}\left(\mathrm{CO}_{3}\right)_{2}$ can alternatively be expressed using the $\mathrm{REECO}_{3}^{+}$or $\operatorname{REE}\left(\mathrm{CO}_{3}\right)_{2}^{-}$aqueous complexes, which leads to small variations in the calculated $D^{\mathrm{REE}}$ for seawater as illustrated by the dashed curves in Fig. $9 \mathrm{~b}$. 
Due to the variation of $K_{D}^{\mathrm{NaREE}\left(\mathrm{CO}_{3}\right)_{2}}$ with the identity of the REE in the lattice strain model, a concave REE pattern is predicted for the partition coefficients, regardless of the aqueous REE complex used in the modelled exchange reaction. This finding is consistent with partition coefficients estimated by Tanaka and Kawabe (2006) for seawater conditions from their coprecipitation results (Fig. 9a). However, their partition coefficients are approximately one order of magnitude higher than those obtained from our experiments. One possible explanation for this difference is the potential precipitation of REE-carbonate as hydroxylbastnasite in their experiments, as PHREEQC calculations suggest that their final reactive fluids are close to saturation with La-hydroxylbastnasite. Nevertheless, the reason for their relatively high $D$ for the heavy REEs remains unclear. Motivated in part by the application to marine limestone, Zhong and Mucci (1995) performed experiments and modelled REE fractionation into calcite at $\mathrm{pH} \sim 8$ in seawater. Thermodynamic calculations, however, suggest that their coprecipitation experiments were highly supersaturated with respect to hydroxylbastnasite, so that their partitioning data may be affected by the precipitation of this mineral. As the solubility of hydroxylbastnasite is the lowest for the light REE, their observations of decreasing partition coefficients from light to heavy REEs as well as the correlations between $c_{\text {REE }}$ and $D^{\mathrm{REE}}$ for the light REEs support this possibility (Fig. 9a). Experimental results of Toyama and Terakado (2014) at $\mathrm{pH} \sim 8.5$ suggest significantly lower partition coefficients, which are likely the result of the high precipitation rates $(\log (\mathcal{R} /$ $\left.\left.\left(\mathrm{mol} / \mathrm{m}^{2} / \mathrm{s}\right)\right) \approx-6.6\right)$ considered in their study. Note a negative correlation between precipitation rate and $D^{\mathrm{REE}}$ was reported by Yeghicheyan (1996) for Eu at fast growth rates (cf. Fig. 6). Our calculated partition coefficients can also be compared to those derived from natural samples (Fig. 9b). Partitioning coefficients inferred from reefal microbialities (Webb and Kamber, 2000), reefal Mg-calcites (Scherer and Seitz, 1980), and foraminifers (Palmer, 
1985) are slightly lower than our calculated values for the light-medium REEs, and the concave pattern is less prominent in these field studies.

One possibility for the differences in reported for REE partitioning between seawater and calcite is the variability of seawater compositions, which affects this partitioning, as illustrated in Fig. 10. As calcite formed in marine sediments is influenced by pore water chemistry, which can be markedly different from that of seawater, this change can also influence the partition coefficients. This is demonstrated by calculating $D^{\mathrm{REE}}$ for the pore water composition taken from the most extremely altered pore water composition (G1, greatest depth) reported by Sholkovitz (1973) for Santa Barbara Basin sediments (Fig. 10, Table 4). Compared to seawater, these waters are characterized by lower sulphate, $\mathrm{Ca}$ and $\mathrm{Mg}$ contents along with significantly higher alkalinity, ammonia and phosphate concentrations. It can be seen that the REE partition coefficients are predicted to decrease significantly with the modification of the seawater compositions in the pores. In addition there is a change in the shape of the partition coefficients as a function of the REE, highlighting the potential influence of pore fluid compositions on these coefficients. Changes in the seawater chemistry during the Earth's history would only lead to minor changes in the $D^{\mathrm{REE}}$ calculated using our model. Taking seawater $\mathrm{Mg}, \mathrm{Ca}$, and $\mathrm{SO}_{4}$ concentrations $(30,25$ and $10 \mathrm{mmol} / \mathrm{kg}$, respectively) estimated for the Cretaceous by Horita et al. (2002), and assuming its equilibrium with an atmospheric $p \mathrm{CO}_{2}$ of $1000 \mathrm{ppm}$ (Royer, 2006) and therefore a lower seawater $\mathrm{pH}, D^{\mathrm{REE}}$ are predicted to be only slightly higher than in present-day seawater (Fig. 10, Table 4). Combining Eq. (7) with Eq. (8), assuming the ratios $a_{\mathrm{Na}^{+}} / c_{\mathrm{Na}}$ and $a_{\mathrm{Ca}^{2+}} / c_{\mathrm{Ca}}$ are constant and ignoring REE complexes, which are present only in minor amounts in seawater $\left(\mathrm{REECl}^{+}, \mathrm{REESO}_{4}^{+}, \mathrm{REEOH}^{2+}, \mathrm{REEHCO}_{3}^{2+}\right.$, cf. Schijf et al. (2015)), a simplified equation for the calculation of $D^{\mathrm{REE}}$ in seawater-like aqueous solutions is obtained: 


$$
D^{\mathrm{REE}}=\frac{x_{1} c_{\mathrm{Na}}}{\left(c_{\mathrm{Ca}}\left(0.45+10^{5} x_{2} a_{\mathrm{CO}_{3}{ }^{2-}}+10^{10} x_{3}\left(a_{\mathrm{CO}_{3}{ }^{2-}}\right)^{2}\right)\right)}
$$

Where $c_{i}$ designate the aqueous concentrations of component $i$ and $x_{j}$ stand for the coefficients shown in Table 4 for the individual REEs, which are based the values of

$K_{D}^{\mathrm{NaREE}\left(\mathrm{CO}_{3}\right)_{2}}$ estimated from our experimental results and their fit to the crystal lattice-strain model. For the case of an aqueous solution in equilibrium with a gas having a $\mathrm{CO}_{2}$ partial pressure, $p \mathrm{CO}_{2}, a_{\mathrm{CO}_{3}{ }^{2-}}$ in equation (11) can be calculated based on thermodynamic constraints using $a_{\mathrm{CO}_{3}{ }^{2-}}=7.1 \times 10^{-19} 10^{2} p \mathrm{H} p \mathrm{CO}_{2}$.

Note again that while these partitioning behaviour predictions are based on the $\operatorname{NaREE}\left(\mathrm{CO}_{3}\right)_{2}$ partitioning reaction (3), it is likely that other exchange reactions dominate REE incorporation into calcite in cases where low $\mathrm{Na}$ concentrations are present in the fluid, leading to a distinct partitioning behaviour. This likely precludes the direct application of this model to processes such as the speleothem formation from cave waters, which typically contain low sodium concentrations compared to our experiments and seawater. Furthermore, the experimental results of Yeghicheyan (1996) suggest an influence of the precipitation rate on partition coefficients at fast growth rates, which may be present in speleothem formation and is not accounted for by our models.

\section{Conclusions}

Analysis of the aqueous solution compositions of the experiments performed in this study confirm that REE are preferentially fractionated into calcite, and the partition coefficients correlate with reactive fluid $c_{\text {REE }}$ as well as its saturation state with respect to calcite. Data interpretation, together with independent spectroscopic evidence (Marques Fernandes et al., 2008; Schmidt, 2009) suggests that the incorporation of $\mathrm{REE}^{3+}$ ions into the calcite structure at near to neutral $\mathrm{pH}$ and the presence of aqueous $\mathrm{NaCl}$ is accompanied by 
the incorporation of $\mathrm{Na}^{+}$. As the REE speciation in our experimental fluids is similar to that of seawater, it is likely that this coupled exchange is predominant during the precipitation of marine limestone from seawater. Partitioning coefficients calculated based on our exchange model for a typical present-day seawater chemistry show a concave pattern as a function of the REE, with a $\log D^{\mathrm{La}}$ of 2.8 , a maximum for $\log D^{\mathrm{Gd}}$ of 3.6 , and decreasing partitioning coefficients towards $D^{\mathrm{Lu}}$ of 2.2. Note, however that these parameters depend strongly the aqueous chemistry, so that Eq. (11) and coefficients in Table 4 should be used to estimate REE partition coefficients between calcite and seawater-like aqueous solutions. This dependence of REE partitioning on the fluid composition gives possibly explains the large variability seen in $D^{\mathrm{REE}}$ inferred from previous experimental studies and from natural calcite.

\section{Acknowledgments}

This research was supported by the CO2-REACT Marie Curie Actions Initial Training Network which was funded by the European Union. The authors would like to thank Frederic Candaudap, Alain Castillo, Thierry Aigouy and Michel Thibaut for help with ICPMS-, BET-, SEM- and XRD- measurements, respectively.

\section{References}

Akagi, T., Kono, Y., 1995. Inhibiting effects of lanthanum ion on calcite formation from $\mathrm{CaCl}_{2}-\mathrm{NaHCO}_{3}$ solutions at $25^{\circ} \mathrm{C}$. Aquat. Geochem. 1, 231-239.

Andreassen, J.-P., 2001. Growth and aggregation phenomena in precipitation of calcium carbonate (PhD Thesis). Norwegian University of Science and Technology.

Azmy, K., Brand, U., Sylvester, P., Gleeson, S.A., Logan, A., Bitner, M.A., 2011. Biogenic and abiogenic low-Mg calcite (bLMC and aLMC): Evaluation of seawater-REE composition, water masses and carbonate diagenesis. Chem. Geol. 280, 180-190. doi:10.1016/j.chemgeo.2010.11.007

Bevington, P.R., Robinson, D.K., 2003. Data Reduction and Error Analysis, 3rd ed. McGraw-Hill, New York.

Blundy, J., Wood, B., 2003. Partitioning of trace elements between crystals and melts. Earth Planet. Sci. Lett. 210, 383-397. doi:10.1016/S0012-821X(03)00129-8

Blundy, J., Wood, B., 1994. Prediction of crystal-melt partition coefficients from elastic moduli. Nature 372, 452-454. 
Böhm, F., Joachimski, M.M., Lehnert, H., Morgenroth, G., Kretschmer, W., Vacelet, J., Dullo, W.-C., 1996. Carbon isotope records from extant Caribbean and South Pacific sponges: Evolution of $\delta^{13} \mathrm{C}$ in surface water DIC. Earth Planet. Sci. Lett. 139, 291303.

Brunauer, S., Emmett, P.H., Teller, E., 1938. Adsorption of gases in multimolecular layers. J. Am. Chem. Soc. 60, 309-319.

Charlton, S.R., Parkhurst, D.L., 2011. Modules based on the geochemical model PHREEQC for use in scripting and programming languages. Comput. Geosci. 37, 1653-1663. doi:10.1016/j.cageo.2011.02.005

Chen, C.-C., Lin, C.-C., Liu, L.-G., Sinogeikin, S.V., Bass, J.D., 2001. Elasticity of singlecrystal calcite and rhodochrosite by Brillouin spectroscopy. Am. Mineral. 86, 15251529.

Collier, A.P., Hounslow, M.J., 1999. Growth and aggregation rates for calcite and calcium oxalate monohydrate. AIChE J. 45, 2298-2305.

Curti, E., Kulik, D.A., Tits, J., 2005. Solid solutions of trace Eu(III) in calcite: Thermodynamic evaluation of experimental data over a wide range of $\mathrm{pH}$ and $\mathrm{pCO}_{2}$. Geochim. Cosmochim. Acta 69, 1721-1737. doi:10.1016/j.gca.2004.06.027

Daveler, S.A., Wolery, T.J., 1992. EQPT, A Data File Preprocessor for the EQ3/6 Software Package: User's Guide and Related Documentation (Version 7.0) (No. UCRL-MA110662 PT II). Lawrence Livermore National Laboratory, Livermore, California, USA.

DePaolo, D.J., 2011. Surface kinetic model for isotopic and trace element fractionation during precipitation of calcite from aqueous solutions. Geochim. Cosmochim. Acta 75, 1039-1056. doi:10.1016/j.gca.2010.11.020

Dromgoole, E.L., Walter, L.M., 1990a. Inhibition of calcite growth rates by $\mathrm{Mn}^{2+}$ in $\mathrm{CaCl}_{2}$ solutions at 10,25 , and $50^{\circ} \mathrm{C}$. Geochim. Cosmochim. Acta 54, 2991-3000. doi:10.1016/0016-7037(90)90116-3

Dromgoole, E.L., Walter, L.M., 1990b. Iron and manganese incorporation into calcite: Effects of growth kinetics, temperature and solution chemistry. Chem. Geol. 81, 311336. doi:10.1016/0009-2541(90)90053-A

Elderfield, H., 1988. The Oceanic Chemistry of the Rare-Earth Elements. Philos. Trans. R. Soc. Lond. Math. Phys. Eng. Sci. 325, 105-126. doi:10.1098/rsta.1988.0046

Elderfield, H., Upstill-Goddard, R., Sholkovitz, E.R., 1990. The rare earth elements in rivers, estuaries, and coastal seas and their significance to the composition of ocean waters. Geochim. Cosmochim. Acta 54, 971-991. doi:10.1016/0016-7037(90)90432-K

Elzinga, E.J., Reeder, R.J., Withers, S.H., Peale, R.E., Mason, R.A., Beck, K.M., Hess, W.P., 2002. EXAFS study of rare-earth element coordination in calcite. Geochim. Cosmochim. Acta 66, 2875-2885. doi:10.1016/S0016-7037(02)00888-8

Fallon, S.J., Guilderson, T.P., Caldeira, K., 2003. Carbon isotope constraints on vertical mixing and air-sea $\mathrm{CO}_{2}$ exchange. Geophys. Res. Lett. 30.

Gabitov, R.I., Sadekov, A., Leinweber, A., 2014. Crystal growth rate effect on $\mathrm{Mg} / \mathrm{Ca}$ and Sr/Ca partitioning between calcite and fluid: An in situ approach. Chem. Geol. 367, 70-82. doi:10.1016/j.chemgeo.2013.12.019

Gautier, Q., Bénézeth, P., Mavromatis, V., Schott, J., 2014. Hydromagnesite solubility product and growth kinetics in aqueous solution from 25 to $75{ }^{\circ} \mathrm{C}$. Geochim. Cosmochim. Acta 138, 1-20. doi:10.1016/j.gca.2014.03.044

Gussone, N., Böhm, F., Eisenhauer, A., Dietzel, M., Heuser, A., Teichert, B.M., Reitner, J., Wörheide, G., Dullo, W.-C., 2005. Calcium isotope fractionation in calcite and aragonite. Geochim. Cosmochim. Acta 69, 4485-4494. 
Helgeson, H.C., 1969. Thermodynamics of hydrothermal systems at elevated temperatures and pressures. Am. J. Sci. 267, 729-804. doi:10.2475/ajs.267.7.729

Henderson, L.M., Kracek, F.C., 1927. The fractional precipitation of barium and radium chromates. J. Am. Chem. Soc. 49, 738-749. doi:10.1021/ja01402a017

Horita, J., Zimmermann, H., Holland, H.D., 2002. Chemical evolution of seawater during the Phanerozoic: Implications from the record of marine evaporites. Geochim. Cosmochim. Acta 66, 3733-3756. doi:10.1016/S0016-7037(01)00884-5

Johannesson, K.H., Stetzenbach, K.J., Hodge, V.F., 1997. Rare earth elements as geochemical tracers of regional groundwater mixing. Geochim. Cosmochim. Acta 61, 3605-3618. doi:10.1016/S0016-7037(97)00177-4

Johnson, J., Anderson, G., Parkhurst, D., 2000. Database "thermo.com.V8.R6.230." Lawrence Livermore Natational Laboratory, Livermore, California, USA.

Karaca, D., Hensen, C., Wallmann, K., 2010. Controls on authigenic carbonate precipitation at cold seeps along the convergent margin off Costa Rica. Geochem. Geophys. Geosystems 11, Q08S27. doi:10.1029/2010GC003062

Klungness, G.D., Byrne, R.H., 2000. Comparative hydrolysis behavior of the rare earths and yttrium: the influence of temperature and ionic strength. Polyhedron 19, 99-107. doi:10.1016/S0277-5387(99)00332-0

Köhler, S.J., Harouiya, N., Chaïrat, C., Oelkers, E.H., 2005. Experimental studies of REE fractionation during water-mineral interactions: REE release rates during apatite dissolution from $\mathrm{pH} 2.8$ to 9.2. Chem. Geol. 222, 168-182. doi:10.1016/j.chemgeo.2005.07.011

Lafuente, B., Downs, R.T., Yang, H., Stone, N., 2015. The power of databases: the RRUFF project, in: Armbruster, T., Danisi, R.M. (Eds.), Highlights in Mineralogical Crystallography. W. De Gruyter, Berlin, Germany, pp. 1-30.

Lakshtanov, L.Z., Stipp, S.L.S., 2007. Experimental study of nickel (II) interaction with calcite: Adsorption and coprecipitation. Geochim. Cosmochim. Acta 71, 3686-3697.

Lakshtanov, L.Z., Stipp, S.L.S., 2004. Experimental study of europium (III) coprecipitation with calcite. Geochim. Cosmochim. Acta 68, 819-827.

Lin, Y.-P., Singer, P.C., 2009. Effect of $\mathrm{Mg}^{2+}$ on the kinetics of calcite crystal growth. J. Cryst. Growth 312, 136-140. doi:10.1016/j.jcrysgro.2009.09.041

Lipin, B.R., McKay, G.A., 1989. Geochemistry and Mineralogy of Rare Earth Elements. Rev. Mineral. Geochem. 21, 348.

Lorens, R.B., 1981. Sr, Cd, Mn and Co distribution coefficients in calcite as a function of calcite precipitation rate. Geochim. Cosmochim. Acta 45, 553-561. doi:10.1016/0016-7037(81)90188-5

Luff, R., Greinert, J., Wallmann, K., Klaucke, I., Suess, E., 2005. Simulation of long-term feedbacks from authigenic carbonate crust formation at cold vent sites. Chem. Geol. 216, 157-174.

Luo, Y.-R., Byrne, R.H., 2004. Carbonate complexation of yttrium and the rare earth elements in natural waters. Geochim. Cosmochim. Acta 68, 691-699. doi:10.1016/S0016-7037(03)00495-2

Luo, Y.-R., Byrne, R.H., 2001. Yttrium and Rare Earth Element Complexation by Chloride Ions at $25^{\circ}$ C. J. Solut. Chem. 30, 837-845. doi:10.1023/A:1012292417793

Marques Fernandes, M., Schmidt, M., Stumpf, T., Walther, C., Bosbach, D., Klenze, R., Fanghänel, T., 2008. Site-selective time-resolved laser fluorescence spectroscopy of $\mathrm{Eu}^{3+}$ in calcite. J. Colloid Interface Sci. 321, 323-331. doi:10.1016/j.jcis.2008.01.017

Mavromatis, V., Gautier, Q., Bosc, O., Schott, J., 2013. Kinetics of Mg partition and Mg stable isotope fractionation during its incorporation in calcite. Geochim. Cosmochim. Acta 114, 188-203. 
Mavromatis, V., Montouillout, V., Noireaux, J., Gaillardet, J., Schott, J., 2015. Characterization of boron incorporation and speciation in calcite and aragonite from co-precipitation experiments under controlled $\mathrm{pH}$, temperature and precipitation rate. Geochim. Cosmochim. Acta 150, 299-313. doi:10.1016/j.gca.2014.10.024

Mavromatis, V., Immenhauser, A., Buhl, D., Purgstaller, B., Baldermann, A., Dietzel, M., 2017. Effect of organic ligands on $\mathrm{Mg}$ partitioning and $\mathrm{Mg}$ isotope fractionation during low-temperature precipitation of calcite in the absence of growth rate effects. Geochimica et Cosmochimica Acta 207, 139-153. doi:10.1016/j.gca.2017.03.020

Millero, F.J., Feistel, R., Wright, D.G., McDougall, T.J., 2008. The composition of Standard Seawater and the definition of the Reference-Composition Salinity Scale. Deep Sea Res. Part Oceanogr. Res. Pap. 55, 50-72. doi:10.1016/j.dsr.2007.10.001

Morse, J.W., 1978. Dissolution kinetics of calcium carbonate in sea water; VI, The nearequilibrium dissolution kinetics of calcium carbonate-rich deep sea sediments. Am. J. Sci. 278, 344-353.

Nielsen, L.C., De Yoreo, J.J., DePaolo, D.J., 2013. General model for calcite growth kinetics in the presence of impurity ions. Geochim. Cosmochim. Acta 115, 100-114. doi:10.1016/j.gca.2013.04.001

Nothdurft, L.D., Webb, G.E., Kamber, B.S., 2004. Rare earth element geochemistry of Late Devonian reefal carbonates, Canning Basin, Western Australia: confirmation of a seawater REE proxy in ancient limestones. Geochim. Cosmochim. Acta 68, 263-283. doi:10.1016/S0016-7037(03)00422-8

Orear, J., 1982. Least squares when both variables have uncertainties. Am. J. Phys. 50, 912. doi:10.1119/1.12972

Palmer, M.R., 1985. Rare earth elements in foraminifera tests. Earth Planet. Sci. Lett. 73, 285-298. doi:10.1016/0012-821X(85)90077-9

Parekh, P.P., Möller, P., Dulski, P., Bausch, W.M., 1977. Distribution of trace elements between carbonate and non-carbonate phases of limestone. Earth Planet. Sci. Lett. 34, 39-50. doi:10.1016/0012-821X(77)90103-0

Parkhurst, D.L., Appelo, C.A.J., 2013. Description of input and examples for PHREEQC version 3 - A computer program for speciation, batch-reaction, one-dimensional transport, and inverse geochemical calculations, in: U.S. Geological Survey Techniques and Methods, Book 6, Chapter A43. U.S. Geological Survey, p. 497.

Plummer, L.N., Busenberg, E., 1982. The solubilities of calcite, aragonite and vaterite in $\mathrm{CO}_{2}-\mathrm{H}_{2} \mathrm{O}$ solutions between 0 and $90^{\circ} \mathrm{C}$, and an evaluation of the aqueous model for the system $\mathrm{CaCO}_{3}-\mathrm{CO}_{2}-\mathrm{H}_{2} \mathrm{O}$. Geochim. Cosmochim. Acta 46, 1011-1040. doi:10.1016/0016-7037(82)90056-4

Royer, D.L., 2006. CO 2-forced climate thresholds during the Phanerozoic. Geochim. Cosmochim. Acta 70, 5665-5675.

Scherer, M., Seitz, H., 1980. Rare-earth element distribution in Holocene and Pleistocene corals and their redistribution during diagenesis. Chem. Geol. 28, 279-289. doi:10.1016/0009-2541(80)90049-2

Schijf, J., Byrne, R.H., 2004. Determination of SO4 $\beta 1$ for yttrium and the rare earth elements at $\mathrm{I}=0.66 \mathrm{~m}$ and $\mathrm{t}=25 \mathrm{C}$-implications for YREE solution speciation in sulfate-rich waters. Geochim. Cosmochim. Acta 68, 2825-2837.

Schijf, J., Christenson, E.A., Byrne, R.H., 2015. YREE scavenging in seawater: A new look at an old model. Mar. Chem. doi:10.1016/j.marchem.2015.06.010

Schmidt, M., 2009. Untersuchungen zum Einbaumechanismus von Actiniden und Lanthaniden in Calcium-haltige Sekundärphasen ( $\mathrm{PhD}$ Thesis). Ruprecht-KarlsUniversität Heidelberg. 
Schnetzler, C.C., Philpotts, J.A., 1970. Partition coefficients of rare-earth elements between igneous matrix material and rock-forming mineral phenocrysts-II. Geochim. Cosmochim. Acta 34, 331-340. doi:10.1016/0016-7037(70)90110-9

Shannon, R.D., 1976. Revised effective ionic radii and systematic studies of interatomic distances in halides and chalcogenides. Acta Crystallogr. A 32, 751-767.

Sholkovitz, E., 1973. Interstitial water chemistry of the Santa Barbara Basin sediments. Geochim. Cosmochim. Acta 37, 2043-2073. doi:10.1016/0016-7037(73)90008-2

Sholkovitz, E., Shen, G.T., 1995. The incorporation of rare earth elements in modern coral. Geochim. Cosmochim. Acta 59, 2749-2756. doi:10.1016/0016-7037(95)00170-5

Stipp, S.L.S., Christensen, J.T., Lakshtanov, L.Z., Baker, J.A., Waight, T.E., 2006. Rare Earth element (REE) incorporation in natural calcite: upper limits for actinide uptake in a secondary phase. Radiochim. Acta 94, 523-528. doi:10.1524/ract.2006.94.911.523

Tai, C.Y., Chen, P.-C., 1995. Nucleation, agglomeration and crystal morphology of calcium carbonate. AIChE J. 41, 68-77.

Tanaka, K., Kawabe, I., 2006. REE abundances in ancient seawater inferred from marine limestone and experimental REE partition coefficients between calcite and aqueous solution. Geochem. J. 40, 425-435. doi:10.2343/geochemj.40.425

Terakado, Y., Masuda, A., 1988. The coprecipitation of rare-earth elements with calcite and aragonite. Chem. Geol. 69, 103-110. doi:10.1016/0009-2541(88)90162-3

Tesoriero, A.J., Pankow, J.F., 1996. Solid solution partitioning of $\mathrm{Sr}^{2+}, \mathrm{Ba}^{2+}$, and $\mathrm{Cd}^{2+}$ to calcite. Geochim. Cosmochim. Acta 60, 1053-1063. doi:10.1016/00167037(95)00449-1

Thien, B.M., Kulik, D.A., Curti, E., 2014. A unified approach to model uptake kinetics of trace elements in complex aqueous-solid solution systems. Appl. Geochem. 41, 135150.

Toyama, K., Terakado, Y., 2014. Experimental study of rare earth element partitioning between calcite and sodium chloride solution at room temperature and pressure. Geochem. J. 48, 463-477. doi:10.2343/geochemj.2.0322

Voigt, M., Rodriguez-Blanco, J.D., Vallina, B., Benning, L.G., Oelkers, E.H., 2016. An experimental study of hydroxylbastnasite solubility in aqueous solutions at $25^{\circ} \mathrm{C}$. Chem. Geol. 430, 70-77. doi:10.1016/j.chemgeo.2016.03.012

Wachi, S., Jones, A.G., 1991. Effect of gas - liquid mass transfer on crystal size distribution during the batch precipitation of calcium carbonate. Chem. Eng. Sci. 46, 3289-3293.

Wasylenki, L.E., Dove, P.M., Wilson, D.S., De Yoreo, J.J., 2005. Nanoscale effects of strontium on calcite growth: An in situ AFM study in the absence of vital effects. Geochim. Cosmochim. Acta 69, 3017-3027. doi:10.1016/j.gca.2004.12.019

Watson, E.B., 2004. A conceptual model for near-surface kinetic controls on the traceelement and stable isotope composition of abiogenic calcite crystals. Geochim. Cosmochim. Acta 68, 1473-1488. doi:10.1016/j.gca.2003.10.003

Webb, G.E., Kamber, B.S., 2000. Rare earth elements in Holocene reefal microbialites: a new shallow seawater proxy. Geochim. Cosmochim. Acta 64, 1557-1565. doi:10.1016/S0016-7037(99)00400-7

Withers, S.H., Peale, R.E., Schulte, A.F., Braunstein, G., Beck, K.M., Hess, W.P., Reeder, R.J., 2003. Broad distribution of crystal-field environments for $\mathrm{Nd}^{3+}$ in calcite. Phys. Chem. Miner. 30, 440-448.

Yeghicheyan, D., 1996. Etude expérimentale du partage des terres rares entre carbonates de calcium et solutions aqueuses: Influence de la cinétique de cristallisation et de la spéciation des terres rares en solution (PhD Thesis). Université Toulouse III-Paul Sabatier. 
Zhong, S., Mucci, A., 1995. Partitioning of rare earth elements (REEs) between calcite and seawater solutions at $25{ }^{\circ} \mathrm{C}$ and 1 atm, and high dissolved REE concentrations. Geochim. Cosmochim. Acta 59, 443-453.

Zhong, S., Mucci, A., 1993. Calcite precipitation in seawater using a constant addition technique: A new overall reaction kinetic expression. Geochim. Cosmochim. Acta 57, 1409-1417. doi:10.1016/0016-7037(93)90002-E

\section{Appendix A. Calculation of partition coefficients and}

\section{precipitation rates}

The relative REE contents of the precipitated calcite are calculated in this study from the composition of the sampled reactive aqueous fluids and mass balance constraints. Assuming steady-state conditions, the molar ratio of REEs and $\mathrm{Ca}$ in the precipitated calcite can be calculated from

$$
\frac{\mathrm{d} n_{\mathrm{REE}}^{\text {Precipitate }}}{\mathrm{d} n_{\mathrm{Ca}}^{\text {Precipitate }}}=\frac{I \mathrm{~d} t\left(c_{\mathrm{REE}}^{\text {Inlet }}-2 c_{\mathrm{REE}}^{\mathrm{SS}}\right)}{I \mathrm{~d} t\left(c_{\mathrm{Ca}}^{\text {Inlet }}-2 c_{\mathrm{Ca}}^{\mathrm{SS}}\right)}=\frac{c_{\mathrm{REE}}^{\text {Inlet }}-2 c_{\mathrm{REE}}^{\mathrm{SS}}}{c_{\mathrm{Ca}}^{\text {Inlet }}-2 c_{\mathrm{Ca}}^{\mathrm{SS}}}
$$

where $c$ stands for the aqueous concentration of the subscripted element in the inlet fluid ('Inlet') or at steady state ('SS') in the reactive fluid, I refers to the injection rate of the inlet fluids, and the factor of two is introduced because two separate aqueous inlet fluids were injected into the reactor at equal pump rates. Using this expression together with Eq. (1), the Henderson-Kracek partition coefficient $\left(D^{\mathrm{REE}}\right)$ for the REEs can be calculated from

$$
D^{\mathrm{REE}}=\frac{c_{\mathrm{REE}}^{\mathrm{Inlet}}-2 c_{\mathrm{REE}}^{\mathrm{SS}}}{c_{\mathrm{Ca}}^{\mathrm{Inlet}}-2 c_{\mathrm{Ca}}^{\mathrm{SS}}} \cdot \frac{c_{\mathrm{Ca}}^{\mathrm{SS}}}{c_{\mathrm{REE}}^{\mathrm{SS}}} .
$$

and a corresponding equation can be used to calculate $D_{\omega}$.

Since the REEs are only incorporated into the precipitating calcite in trace amounts, the surface area normalized molar calcite precipitation rate (or growth rate), $\mathcal{R}$, at time $t$ can be calculated from the aqueous solution $\mathrm{Ca}$ concentrations once steady-state is attained. Calcium mass balance in the reactor requires 


$$
\frac{\mathrm{d} n_{\mathrm{Ca}}^{\text {Precip }}}{\mathrm{d} t}+\frac{\mathrm{d} n_{\mathrm{Ca}}^{\mathrm{SS}}}{\mathrm{d} t}=\frac{\mathrm{d} n_{\mathrm{Ca}}^{\text {Injected }}}{\mathrm{d} t}
$$

with $\mathrm{d} n$ denoting the change in $n$ in a certain time step $\mathrm{d} t$, and the superscripts 'Precip', 'SS' and 'Injected' denoting the precipitated calcium, the calcium in the aqueous solution in the reactor at steady state, and in the total $\mathrm{Ca}$ entering the reactor from the two inlet solutions, respectively. As the increase of fluid mass in the reactor is equal to $2 I$,

$$
\frac{\mathrm{d} n_{\mathrm{Ca}}^{\text {Precip }}}{\mathrm{d} t}+c_{\mathrm{Ca}}^{\mathrm{SS}} 2 I=c_{\mathrm{Ca}}^{\text {Inlet } I}
$$

assuming constant $c_{\mathrm{Ca}}^{\mathrm{SS}}$. Because the calcite precipitation rate at time $t$ is defined as $\mathcal{R}_{t}^{\mathrm{Ca}} \equiv$ $\mathrm{d} n_{\mathrm{Ca}}^{\text {Precip }} /\left(S_{t} m_{t}^{\text {Calcite }} \mathrm{d} t\right)$, Eq. (A.4) can be rewritten

$$
\mathcal{R}_{t}^{\mathrm{Ca}}=\frac{I\left(c_{\mathrm{Ca}}^{\text {Inlet }}-2 c_{\mathrm{Ca}}^{\mathrm{SS}}\right)}{m_{t}^{\text {Calcite }} S_{t}}
$$

where $m_{t}^{\text {Calcite }}$ designates the mass of calcite in the reactor at time $t$, and $S_{t}$ refers to the specific surface of the calcite at time $t$. As the rate at which $m_{t}^{\text {Calcite }}$ changes over time can be approximated as

$$
\frac{\mathrm{d} m_{t}^{\text {Calcite }}}{\mathrm{d} t}=I\left(c_{\mathrm{Ca}}^{\text {Inlet }}-2 c_{\mathrm{Ca}}^{\mathrm{SS}}\right) M^{\text {Calcite }}
$$

where $M^{\text {Calcite }}$ refers to the molar mass of calcite, the amount of calcite precipitated from a time $t$ until the end of the experiment $t_{\text {End }}$ is given by

$$
m_{\text {End }}^{\text {Calcite }}-m_{t}^{\text {Calcite }}=\left(t_{\text {End }}-t\right)\left(c_{\mathrm{Ca}}^{\text {Inlet }}-2 c_{\mathrm{Ca}}^{\mathrm{SS}}\right) I M^{\text {Calcite }}
$$

Assuming that the specific surface area changes from the initial value $S_{0}$ to the final value $S_{\text {End }}$ proportionally with the increase in calcite mass, it can be approximated as

$$
S_{t}=\frac{m_{\text {End }}^{\text {Calcite }} S_{0}-m_{\text {Seeds }} S_{\text {End }}+m_{t}^{\text {Calcite }}\left(S_{\text {End }}-S_{0}\right)}{m_{\text {End }}^{\text {Calcite }}-m_{\text {Seeds }}} .
$$


where $m_{\text {Seeds }}$ is the initial mass of calcite seeds present in the reactor, which allows the calculation of $\mathcal{R}_{t}^{\mathrm{Ca}}$. Furthermore, the rates can be calculated independently using the equivalent equations and alkalinity measurements according to

$$
\mathcal{R}_{t}^{\mathrm{Alk}}=\frac{I\left(c_{\mathrm{Alk}}^{\text {Inlet }}-2 c_{\mathrm{Alk}}^{\mathrm{SS}}\right)}{m_{t}^{\text {Calcite }} S_{t}} .
$$

\section{Appendix B. Theoretical demonstration of attainment of steady}

\section{state}

As described in section 3.1, the reactors in our study contained an initial mass of calcite-saturated solution, but this mass gradually increased as fluid is injected into the reactor and calcite precipitated. This experimental method has the advantage of being able to start the experiment with a small volume of aqueous solution in the reactor, leading to a rapid attainment of steady-state. Taking account of the reactor design, the rate of calcite growth can be computed using

$$
A \int_{0}^{t} \mathcal{R} d t=n_{\mathrm{Ca}}^{\mathrm{Inlet}}-\left(n_{\mathrm{Ca}}^{t}-n_{\mathrm{Ca}}^{0}\right)
$$

where $A$ refers to the calcite surface area, $t$ signifies the time, and $n_{\mathrm{Ca}}^{\mathrm{Inlet}}, n_{\mathrm{Ca}}^{t}$ and $n_{\mathrm{Ca}}^{0}$ are the total molar amounts of calcium in the inlet reservoir fluid, in the reactor fluid at time $t$ and at the beginning of the experiment, respectively. For a constant pump injection rate, $I$, the total mass of injected fluid equals $I t$, and it follows that

$$
A \int_{0}^{t} \mathcal{R} d t=\left(c_{\mathrm{Ca}}^{\text {Inlet }}-2 c_{\mathrm{Ca}}^{t}\right) I t+\left(c_{\mathrm{Ca}}^{0}-c_{\mathrm{Ca}}^{t}\right) m_{\text {Fluid }}^{0}
$$

where $c_{\mathrm{Ca}}$ stands for the concentration of calcium in the corresponding aqueous fluid and $m_{\text {Fluid }}^{0}$ is the initial fluid mass in the reactor. The factor of two is introduced because two separate aqueous fluids were pumped into the reactor at equal pump rates, such that the volume in the reactor increases at twice the pump rate. It can be seen that for $t \rightarrow \infty$ (after 
the initial phase of the experiment), the second term on the right hand side of this equation becomes negligible and the equation becomes identical to equation (2) in Zhong and Mucci (1993) so that their theoretical argumentation for the attainment of steady-state can also be applied to our experimental design.

\section{Appendix C. Relationship between $D^{\mathrm{REE}}$ and $K_{D}$}

The relationship between the partition coefficient $D^{\mathrm{REE}}$, which is defined by Eq. (1), and the equilibrium constant $K_{D}^{\mathrm{NaREE}\left(\mathrm{CO}_{3}\right)_{2}}$, defined by Eq. (4), can be derived by combining the relationships

$$
\begin{gathered}
D^{\mathrm{REE}} \approx \frac{X_{\mathrm{REE}}^{\text {Calcite }}}{c_{\mathrm{REE}}^{\text {Fluid }} / c_{\mathrm{Ca}}^{\text {Fluid }}} \\
K_{D}^{\mathrm{NaREE}\left(\mathrm{CO}_{3}\right)_{2}} \approx \frac{2 X_{\mathrm{REE}}^{\text {Calcite }}\left(a_{\mathrm{Ca}^{2+}}\right)^{2}}{a_{\mathrm{REE}^{3+}} a_{\mathrm{Na}^{+}}} \\
a_{R E E_{i}}=c_{R E E_{i}} \gamma_{R E E_{i}} \\
\sum c_{R E E_{i}}=c_{\mathrm{REE}}^{\mathrm{Fluid}}
\end{gathered}
$$

for the aqueous species containing REEs " $R E E_{i}$ " with the stability constants for the REEcarbonate complexes $\left(K_{\mathrm{REECO}}^{+}, K_{\mathrm{REE}\left(\mathrm{CO}_{3}\right)_{2}^{-}}\right.$and $K_{\mathrm{REEHCO}_{3}^{2+}}$ as defined by ${ }_{\mathrm{CO} 3} \beta_{1}^{0}, \mathrm{CO}_{3} \beta_{2}^{0}$ and ${ }_{\mathrm{HCO}} \beta_{1}^{0}$ in Luo and Byrne (2004)) and $\mathrm{CO}_{2}-\mathrm{H}_{2} \mathrm{O}$ equilibria $\left(K_{2}\right.$ as defined in Plummer and Busenberg (1982)). Solving this system of equations for the relevant aqueous REE species at our experimental conditions $\left(\mathrm{REE}^{3+}, \mathrm{REECO}_{3}^{+}, \mathrm{REE}\left(\mathrm{CO}_{3}\right)_{2}^{-}\right.$and $\mathrm{REEHCO}_{3}^{2+}$ ) yields Eq. (7), and similar equations can be derived if other aqueous REE species are present in significant amounts (e.g. in seawater). 


\section{Figures}

Fig. 1: Schematic illustration of the experimental design used for the co-precipitation experiments reported in this study.

Fig. 2: SEM images of the synthetic calcite powder before the experiments (a) and after precipitation experiments CP12 (b), in which no REEs were added, and CP14 (c) where REEs were present in the reactor aqueous solution.

Fig. 3: Temporal evolution of the $\mathrm{pH}$, aqueous calcium concentration, alkalinity and aqueous lanthanum concentration in the reactive fluids the reactor during experiment CP15.

Fig. 4: Relationship between the partition coefficient $D^{\mathrm{REE}}$, (a) the steady state aqueous REE concentrations, and (b) the calcite saturation sate $\Omega$ in our experiments. The symbols labelled as ' $\mathrm{La}+\mathrm{Yb}$ ' are experiments spiked with both $\mathrm{La}$ and $\mathrm{Yb}$, and the REE named in parentheses is the one plotted using the corresponding symbol.

Fig. 5 Relationship between the effective ionic radii $r$ of the REEs and the equilibrium distribution coefficient of the exchange mechanism involving $\mathrm{NaREE}\left(\mathrm{CO}_{3}\right)_{2}$. The red circles show experimental results from our experiments $(\mathrm{La}, \mathrm{Yb})$ and those of Lakshtanov and Stipp (2004) $(\mathrm{Eu})$. The blue curve depicts the best fit to the lattice strain model of Blundy and Wood (1994).

Fig. 6: Relationship between the logarithm of the partition coefficient $D^{\mathrm{REE}}$ and the logarithmic calcite precipitation rate. The symbols represent our experimental data (see Fig. 4 for a legend). The dark and light grey areas show the range of values obtained by Zhong and Mucci (1995) for a mix of REEs and Lakshtanov and Stipp (2004) for Eu, respectively, while the orange line shows a best fit equation determined by Yeghicheyan (1996) for the correlation they observed using Eu.

Fig. 7: Plot of the reactive fluid saturation state with respect to calcite, expressed as $\Omega$-1, vs. the calcite growth rate $\mathcal{R}$ for REE free experiments (red points). The blue curve shows the best fit to the empirical rate law (Morse, 1978).

Fig. 8: Plot illustrating the inhibitory effect of the REEs on calcite growth assuming a correlation between the $\mathrm{Ca}^{2+}$ surface site concentration and the growth rate, implying a linear relationship between the logarithms of $\left(\mathcal{R}_{0}-\mathcal{R}\right) / \mathcal{R}$ and $\sum c_{\mathrm{REE}} / a_{\mathrm{Ca}^{2+}}$. The blue line shows a best fit equation of this model.

Fig. 9: (a) Comparison of the partition coefficients $D^{\mathrm{REE}}$, calculated from experimental $K_{D}^{\mathrm{NaREE}}\left(\mathrm{CO}_{3}\right)_{2}$ and the best fit to the lattice strain model for a seawater matrix (Millero et al., 2008) to experimental data of Zhong and Mucci (1995), Tanaka and Kawabe (2006) and Toyama and Terakado (2014). (b) Comparison of the same calculated $D$ to partition coefficients calculated from natural samples: Reefal microbialities (Webb and Kamber, 2000), reefal Mg-calcites (Scherer and Seitz, 1980), and foraminifers (Palmer, 1985). The dashed curves show the best of our $K_{D}^{\mathrm{NaREE}\left(\mathrm{CO}_{3}\right)_{2}}$ model, but using $\operatorname{REECO}_{3}^{+}$and $\operatorname{REE}\left(\mathrm{CO}_{3}\right)_{2}^{-}$ in the exchange reaction instead of $\mathrm{REE}^{3+}$.

Fig. 10: Partition coefficients calculated from experimental $K_{D}^{\mathrm{NaREE}\left(\mathrm{CO}_{3}\right)_{2}}$ and the best fit to the lattice strain model determined by us for variations in seawater compositions based on Millero et al. (2008), which is shown by the red curve. The blue curve demonstrates the effect 
of the pore water chemistry, represented by the chemistry of the most extremely altered composition reported by Sholkovitz (1973), while the green curve illustrates partition coefficients calculated for Cretaceous seawater $\mathrm{Mg}, \mathrm{Ca}$ and $\mathrm{SO}_{4}$ concentrations estimated by Horita et al. (2002) in equilibrium with a $p \mathrm{CO}_{2}$ of $1000 \mathrm{ppm}$.

\section{Supplementary data}

Supplementary Fig. S1: Comparison of the XRD profile of calcite (taken from the RRUFF database, Lafuente et al., 2015) to that of the solid material recovered after experiment CP13 of the experiments in our study. 


\section{Tables}

Table 1: Summary of experimental conditions, measured composition of the inlet fluids and average composition of the reactor fluid after attainment of steady state (SS) in all experiments.

\begin{tabular}{|c|c|c|c|c|c|c|c|c|c|c|c|c|c|c|}
\hline $\begin{array}{l}\text { Exp. } \\
\text { ID }\end{array}$ & $\mathrm{pH}$ & $\begin{array}{c}c_{\mathrm{Ca}}^{\text {Inlet }} / \\
(\mathrm{mmol} / \mathrm{kg}) \\
\end{array}$ & $\begin{array}{c}c_{\mathrm{Ca}}^{\mathrm{SS}} / \\
(\mathrm{mmol} / \mathrm{kg})\end{array}$ & $\begin{array}{c}c_{\text {Alk }}^{\text {Inlet }} / \\
(\mathrm{meq} / \mathrm{kg})\end{array}$ & $\begin{array}{c}c_{\mathrm{Alk}}^{\mathrm{SS}} / \\
(\mathrm{meq} / \mathrm{kg})\end{array}$ & $\begin{array}{c}c_{\mathrm{La}}^{\text {Inlet }} / \\
(\mu \mathrm{mol} / \mathrm{kg})\end{array}$ & $\begin{array}{c}c_{\mathrm{La}}^{\mathrm{SS}} / \\
(\mathrm{nmol} / \mathrm{kg}) \\
\end{array}$ & $\begin{array}{c}c_{\mathrm{Yb}}^{\text {Inlet }} / \\
(\mu \mathrm{mol} / \mathrm{kg}) \\
\end{array}$ & $\begin{array}{c}c_{\mathrm{Yb}}^{\mathrm{SS}} / \\
(\mathrm{nmol} / \mathrm{kg})\end{array}$ & I / (g/day) & $\begin{array}{c}m_{\text {Seeds }} \\
/ \mathrm{g}\end{array}$ & $\begin{array}{c}m_{\text {Precip }} \\
/ \mathrm{g}\end{array}$ & $\begin{array}{c}\text { Duration } \\
\text { / days }\end{array}$ & $\begin{array}{c}S_{\text {End }} / \\
\left(\mathrm{m}^{2} / \mathrm{g}\right)\end{array}$ \\
\hline CP12 & 6.02 & $110.3 \pm 1.1$ & $13.70 \pm 0.85$ & $99.1 \pm 1.5$ & $12.24 \pm 0.35$ & - & - & - & - & $19.76 \pm 0.07$ & 0.994 & 0.39 & 3 & 0.348 \\
\hline CP13 & 6.03 & $109.4 \pm 1.4$ & $16.0 \pm 1.1$ & $98.6 \pm 1.8$ & $12.37 \pm 0.30$ & $4.774 \pm 0.044$ & $1.48 \pm 0.25$ & - & - & $20.03 \pm 0.20$ & 1.027 & 0.35 & 3 & 0.356 \\
\hline CP15 & 6.06 & $87.10 \pm 0.67$ & $15.0 \pm 1.0$ & $78.9 \pm 1.4$ & $13.26 \pm 0.33$ & $4.749 \pm 0.043$ & $2.39 \pm 0.43$ & - & - & $19.62 \pm 0.32$ & 1.000 & 0.20 & 3 & 0.554 \\
\hline CP16 & 6.43 & $92.75 \pm 0.72$ & $28.2 \pm 5.2$ & $98.6 \pm 1.8$ & $31.25 \pm 0.59$ & $4.702 \pm 0.075$ & $39.6 \pm 3.1$ & $3.776 \pm 0.053$ & $104 \pm 15$ & $17.29 \pm 0.30$ & 1.038 & 0.20 & 7 & 0.459 \\
\hline CP19 & 6.18 & $139.4 \pm 1.4$ & $14.88 \pm 0.95$ & $147.2 \pm 2.4$ & $17.40 \pm 0.33$ & $4.673 \pm 0.088$ & $6.3 \pm 1.0$ & - & - & $19.05 \pm 0.38$ & 0.753 & 1.29 & 7 & 0.626 \\
\hline CP21 & 6.32 & $92.9 \pm 1.1$ & $19.0 \pm 1.3$ & $99.2 \pm 2.0$ & $23.17 \pm 0.36$ & $2.396 \pm 0.029$ & $7.9 \pm 1.3$ & $2.291 \pm 0.024$ & $24.0 \pm 3.8$ & $8.46 \pm 0.57$ & 0.749 & 0.46 & 13 & 0.437 \\
\hline CP22 & 6.15 & $66.8 \pm 1.2$ & $13.85 \pm 0.81$ & $68.9 \pm 1.4$ & $15.23 \pm 0.32$ & $4.467 \pm 0.070$ & $3.45 \pm 0.29$ & - & - & $9.14 \pm 0.61$ & 2.012 & 0.33 & 13 & 0.455 \\
\hline CP23 & 6.13 & $65.1 \pm 1.3$ & $13.44 \pm 0.75$ & $69.3 \pm 1.3$ & $14.29 \pm 0.32$ & $2.380 \pm 0.033$ & $2.04 \pm 0.83$ & $2.274 \pm 0.028$ & $2.21 \pm 0.37$ & $9.24 \pm 0.62$ & 1.996 & 0.38 & 13 & 0.477 \\
\hline $\mathrm{CP} 24$ & 6.16 & $94.1 \pm 1.6$ & $12.15 \pm 0.73$ & $99.8 \pm 1.9$ & $15.22 \pm 0.83$ & $4.698 \pm 0.084$ & $4.6 \pm 1.5$ & - & - & $16.99 \pm 0.82$ & 0.997 & 0.73 & 7 & 0.454 \\
\hline CP25 & 6.19 & $95.1 \pm 1.9$ & $11.82 \pm 0.76$ & $98.8 \pm 2.0$ & $15.9 \pm 1.1$ & $4.676 \pm 0.077$ & $4.72 \pm 0.38$ & - & - & $17.2 \pm 1.1$ & 0.998 & 0.74 & 7 & 0.404 \\
\hline CP26 & 6.11 & $86.9 \pm 1.7$ & $15.3 \pm 1.1$ & $98.5 \pm 1.5$ & $13.66 \pm 0.94$ & $3.228 \pm 0.051$ & $3.26 \pm 0.61$ & $2.440 \pm 0.029$ & $3.34 \pm 0.69$ & $17.10 \pm 0.83$ & 1.006 & 0.82 & 7 & 0.539 \\
\hline CP27 & 6.22 & $64.9 \pm 1.4$ & $17.6 \pm 1.4$ & $69.0 \pm 1.5$ & $17.2 \pm 1.1$ & $4.535 \pm 0.074$ & $17.2 \pm 1.3$ & - & - & $17.34 \pm 0.70$ & 2.000 & 0.23 & 7 & 0.417 \\
\hline CP28 & 6.17 & $91.94 \pm 0.83$ & $13.43 \pm 0.17$ & $89.7 \pm 1.9$ & $15.27 \pm 0.30$ & $5.042 \pm 0.099$ & $8.0 \pm 3.5$ & - & - & $9.08 \pm 0.04$ & 0.997 & 0.11 & 11 & 0.422 \\
\hline CP31 & 6.18 & $67.35 \pm 0.45$ & $15.81 \pm 0.51$ & $69.8 \pm 1.4$ & $16.14 \pm 0.39$ & $4.993 \pm 0.096$ & $9.5 \pm 2.1$ & - & - & $8.51 \pm 0.03$ & 1.996 & 0.06 & 11 & 0.449 \\
\hline CP34 & 6.09 & $95.11 \pm 0.72$ & $13.39 \pm 0.18$ & $96.9 \pm 1.5$ & $11.96 \pm 0.87$ & - & - & - & - & $44.6 \pm 1.0$ & 1.005 & 0.80 & 4 & 0.563 \\
\hline
\end{tabular}


Table 2: Calculated parameters of all experiments during steady state. $\Omega_{\mathrm{La}-\mathrm{HB}}$ designates the La-hydroxylbastnasite saturation state.

\begin{tabular}{|c|c|c|c|c|c|c|c|}
\hline $\begin{array}{l}\text { Exp. } \\
\text { ID } \\
\end{array}$ & $\begin{array}{c}\log (\mathcal{R} / \\
\left.\left(\mathrm{mol} / \mathrm{m}^{2} / \mathrm{s}\right)\right) \\
\end{array}$ & $\Omega_{\text {Calcite }}$ & $\log \left(\Omega_{\mathrm{La}-\mathrm{HB}}\right)$ & $\begin{array}{l}X_{\mathrm{La}}^{\text {Precipitate }} \\
\quad \times 10^{5} \\
\end{array}$ & $\begin{array}{l}X_{\mathrm{Yb}}^{\text {Precipitate }} \\
\quad \times 10^{5} \\
\end{array}$ & $\log D^{\mathrm{La}}$ & $\log D^{\mathrm{Yb}}$ \\
\hline CP12 & $-7.31 \pm 0.25$ & $1.11 \pm 0.09$ & & - & - & - & \\
\hline CP13 & $-7.40 \pm 0.23$ & $1.28 \pm 0.12$ & $-1.51 \pm 0.07$ & $6.16 \pm 0.21$ & - & $2.827 \pm 0.058$ & - \\
\hline CP14 & $-7.58 \pm 0.34$ & $1.35 \pm 0.17$ & - & - & $5.99 \pm 0.32$ & - & $2.694 \pm 0.073$ \\
\hline CP15 & $-7.50 \pm 0.21$ & $1.38 \pm 0.13$ & $-1.24 \pm 0.08$ & $8.30 \pm 0.32$ & - & $2.721 \pm 0.060$ & - \\
\hline CP16 & $-7.75 \pm 0.48$ & $11.0 \pm 1.9$ & $0.59 \pm 0.04$ & $12.7 \pm 3.7$ & $9.8 \pm 2.8$ & $1.96 \pm 0.21$ & $1.43 \pm 0.21$ \\
\hline CP19 & $-7.50 \pm 0.54$ & $2.05 \pm 0.18$ & $-0.63 \pm 0.09$ & $4.25 \pm 0.12$ & - & $2.007 \pm 0.077$ & - \\
\hline CP21 & $-7.91 \pm 0.33$ & $4.85 \pm 0.45$ & $-0.27 \pm 0.07$ & $4.33 \pm 0.23$ & $4.08 \pm 0.21$ & $2.022 \pm 0.052$ & $1.512 \pm 0.067$ \\
\hline CP22 & $-8.29 \pm 0.40$ & $1.78 \pm 0.16$ & $-0.91 \pm 0.05$ & $11.41 \pm 0.61$ & - & $2.662 \pm 0.047$ & - \\
\hline $\mathrm{CP} 23$ & $-8.31 \pm 0.41$ & $1.58 \pm 0.13$ & $-1.2 \pm 0.2$ & $6.22 \pm 0.34$ & $5.94 \pm 0.32$ & $2.63 \pm 0.17$ & $2.562 \pm 0.059$ \\
\hline $\mathrm{CP} 24$ & $-7.66 \pm 0.34$ & $1.64 \pm 0.15$ & $-0.8 \pm 0.1$ & $6.72 \pm 0.24$ & - & $2.27 \pm 0.14$ & - \\
\hline $\mathrm{CP} 25$ & $-7.68 \pm 0.26$ & $1.77 \pm 0.16$ & $-0.69 \pm 0.05$ & $6.53 \pm 0.25$ & - & $2.215 \pm 0.040$ & - \\
\hline CP26 & $-7.83 \pm 0.38$ & $1.62 \pm 0.15$ & $-1.02 \pm 0.09$ & $5.73 \pm 0.29$ & $4.33 \pm 0.22$ & $2.435 \pm 0.080$ & $2.304 \pm 0.076$ \\
\hline CP27 & $-8.09 \pm 0.33$ & $2.86 \pm 0.28$ & $-0.09 \pm 0.06$ & $15.2 \pm 1.6$ & - & $2.191 \pm 0.080$ & - \\
\hline CP28 & $-7.71 \pm 0.45$ & $1.83 \pm 0.13$ & $-0.5 \pm 0.2$ & $7.4 \pm 1.8$ & - & $2.11 \pm 0.22$ & - \\
\hline CP31 & $-8.26 \pm 0.55$ & $2.24 \pm 0.16$ & $-0.4 \pm 0.1$ & $14.4 \pm 4.2$ & - & $2.36 \pm 0.15$ & - \\
\hline CP32 & $-7.85 \pm 0.28$ & $1.03 \pm 0.08$ & - & - & - & - & - \\
\hline CP34 & $-6.96 \pm 0.11$ & $1.25 \pm 0.09$ & - & - & - & - & - \\
\hline
\end{tabular}


Table 3: Best model fit estimates and standard errors $(S E)$ for equilibrium constants $K_{D}$ for different exchange reactions of REEs between an aqueous solution and calcite calculated for our experimental data. The experimental data of Lakshtanov and Stipp (2004) was used to calculate the values for $\mathrm{NaEu}\left(\mathrm{CO}_{3}\right)_{2}$ and $\mathrm{HEu}\left(\mathrm{CO}_{3}\right)_{2}$.

\begin{tabular}{crl}
\hline $\begin{array}{c}\text { Solid REE } \\
\text { endmember }\end{array}$ & \multicolumn{1}{c}{$K_{D}$} & \multicolumn{1}{l}{$S E$} \\
\hline $\mathrm{NaLa}\left(\mathrm{CO}_{3}\right)_{2}$ & 2.399 & 0.046 \\
$\mathrm{NaYb}\left(\mathrm{CO}_{3}\right)_{2}$ & 3.266 & 0.049 \\
$\mathrm{La}_{2} \mathrm{X}\left(\mathrm{CO}_{3}\right)_{3}$ & 8.613 & 0.067 \\
$\mathrm{Yb} \mathrm{X}_{2}\left(\mathrm{CO}_{3}\right)_{3}$ & 10.494 & 0.082 \\
$\mathrm{HLa}\left(\mathrm{CO}_{3}\right)_{2}$ & 7.443 & 0.042 \\
$\mathrm{HYb}\left(\mathrm{CO}_{3}\right)_{2}$ & 8.249 & 0.050 \\
$\mathrm{NaEu}\left(\mathrm{CO}_{3}\right)_{2}$ & 3.821 & 0.041 \\
$\mathrm{HEu}\left(\mathrm{CO}_{3}\right)_{2}$ & 8.534 & 0.039 \\
\hline
\end{tabular}




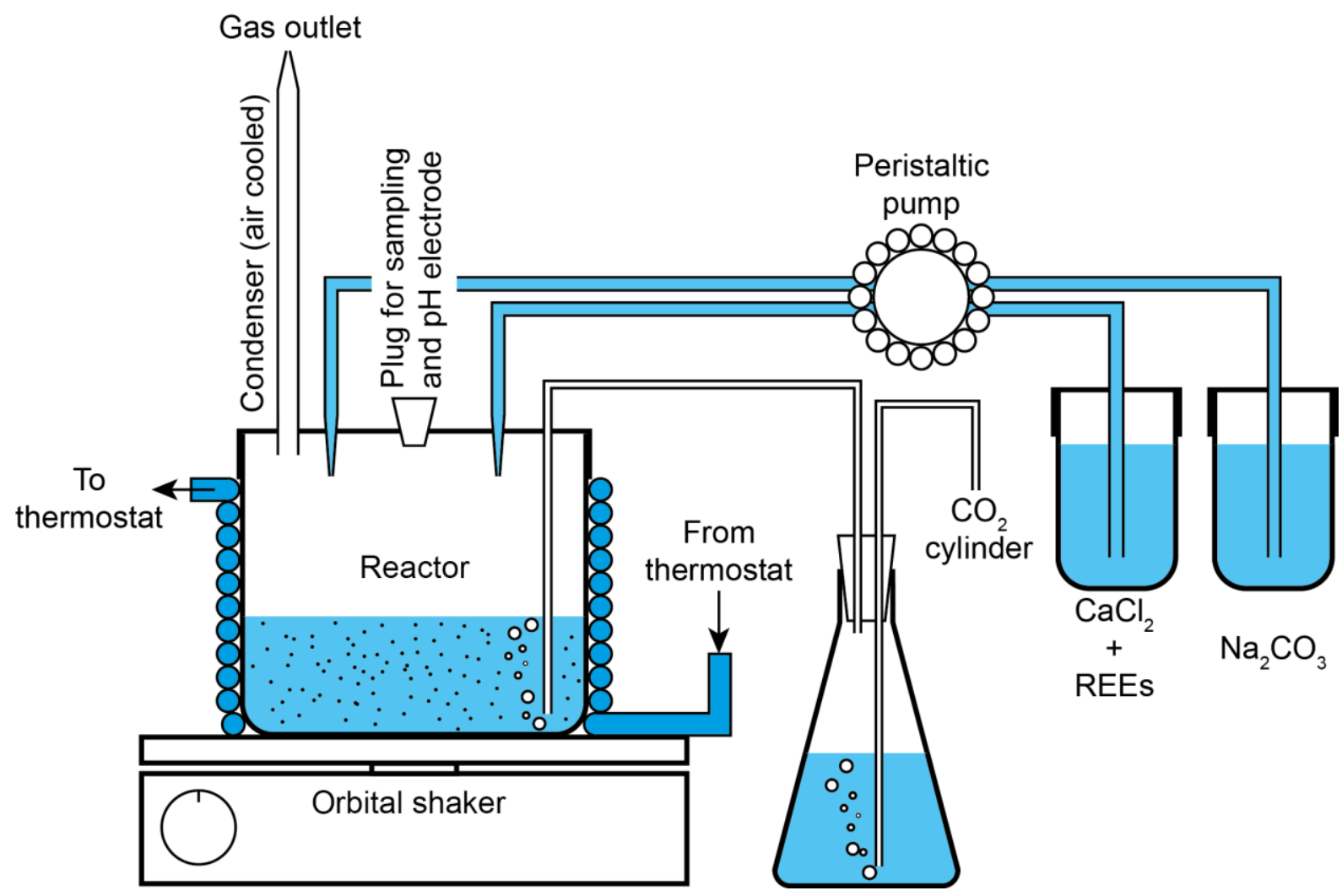

Figure 11

Schematic illustration of the experimental design used for the co-precipitation experiments in this study. 

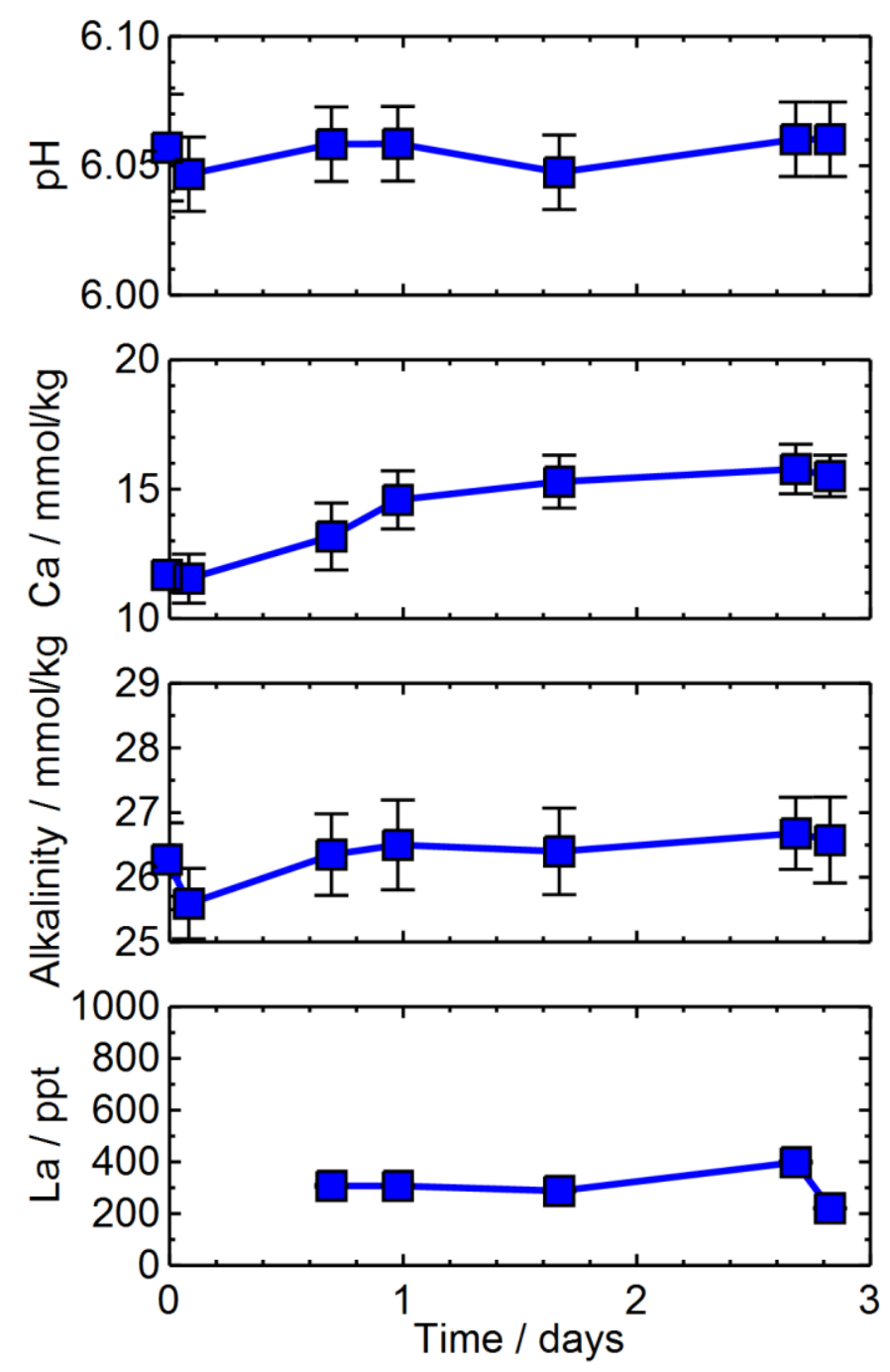

Figure 12

Temporal evolution of $\mathrm{pH}$, calcium concentration, alkalinity and lanthanum concentration in the experimental solution the reactor during experiment CP15. 

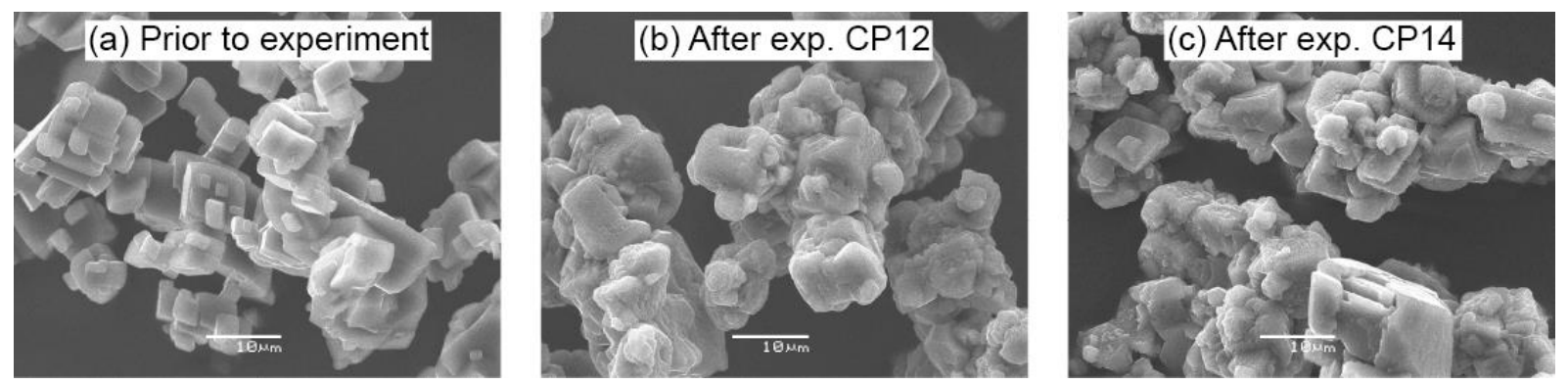

Figure 13

SEM images of the synthetic calcite powder before the experimental run (a) and after precipitation experiments CP12 (b), in which no REEs were added, and CP14 (c) where REEs were present in the reactor solution. 


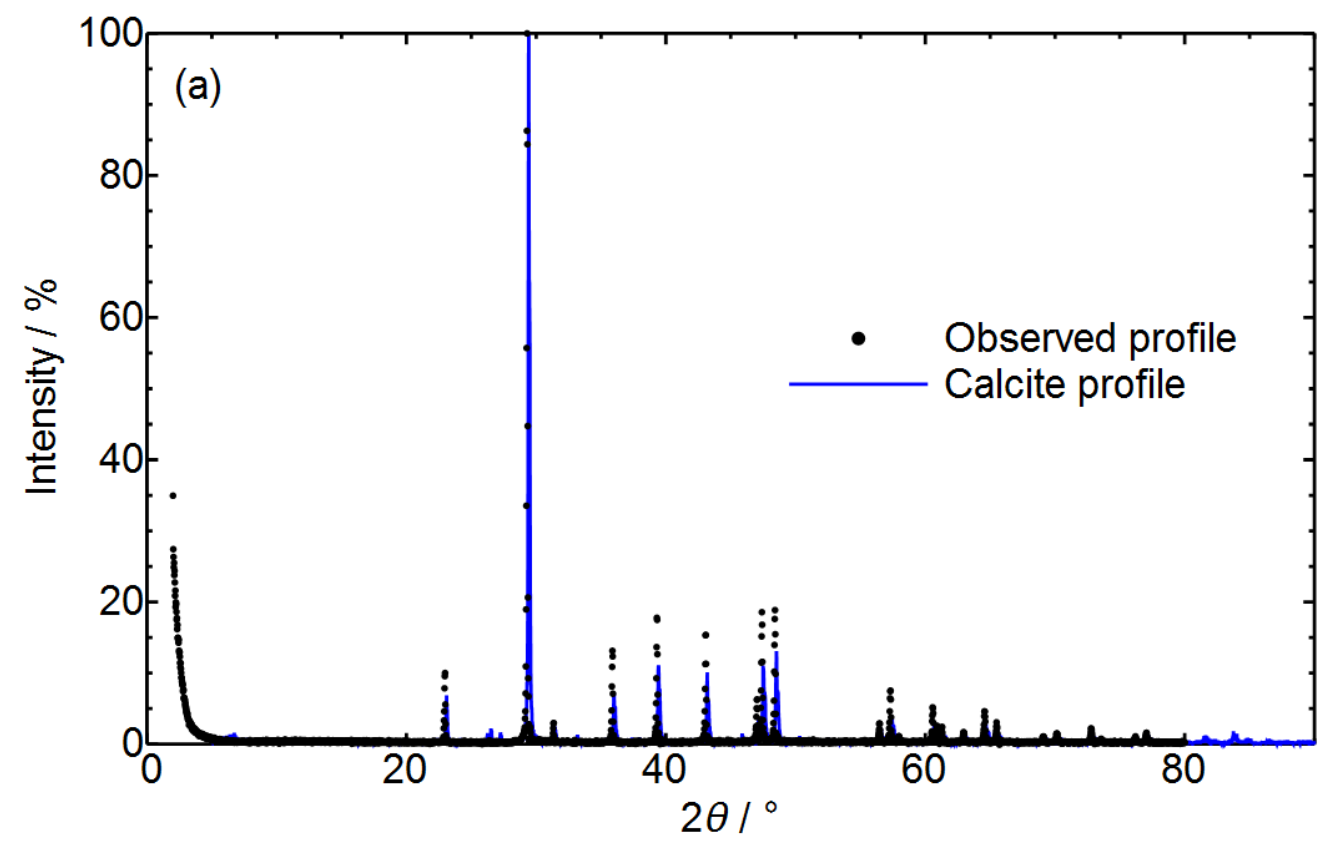

Figure 14

Comparison of the XRD profile of calcite (taken from the RRUFF database, Lafuente et al., 2015) to XRD pattern of the solid material recovered after experiment CP13 of the experiments in our study. 


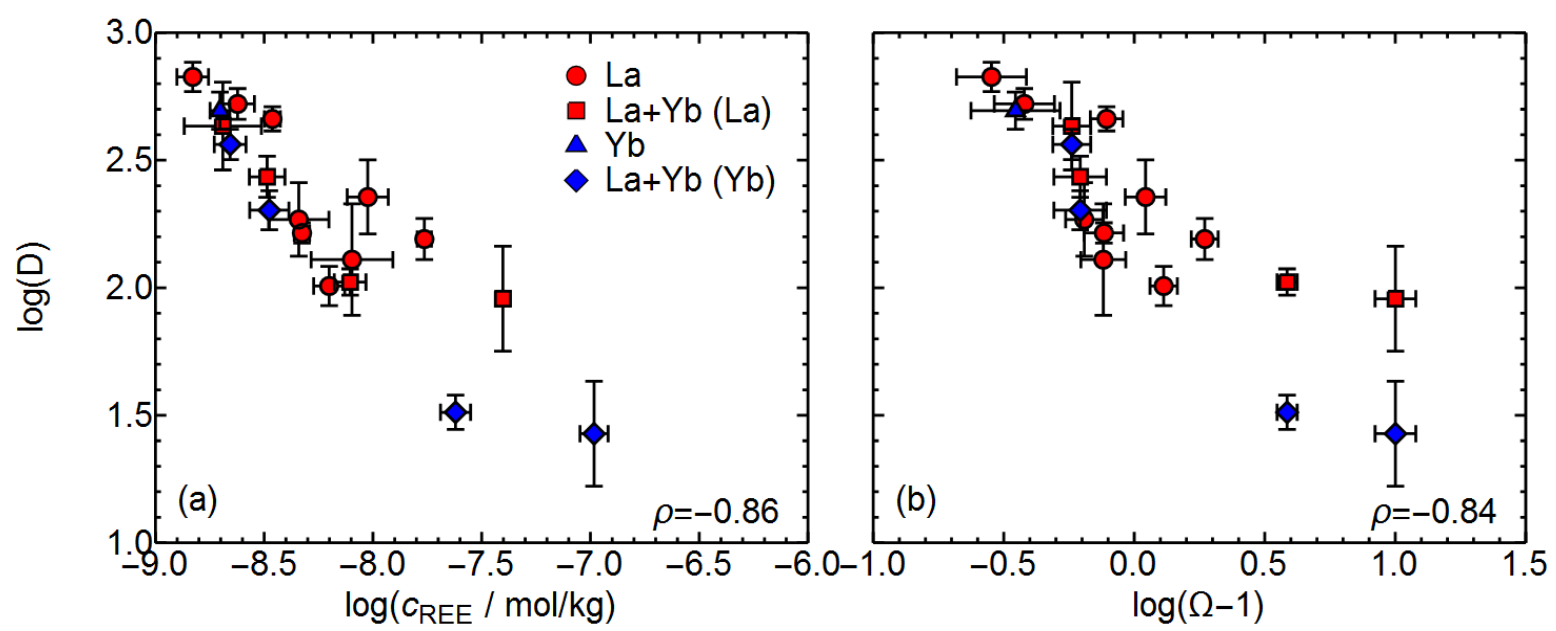

Figure 15

Relationship between the partition coefficient $D$, (a) the steady state aqueous REE concentrations, and (b) the calcite saturation sate $\Omega$ in our experiments. The symbols labelled as ' $\mathrm{La}+\mathrm{Yb}$ ' are experiments spiked with both $\mathrm{La}$ and $\mathrm{Yb}$. 


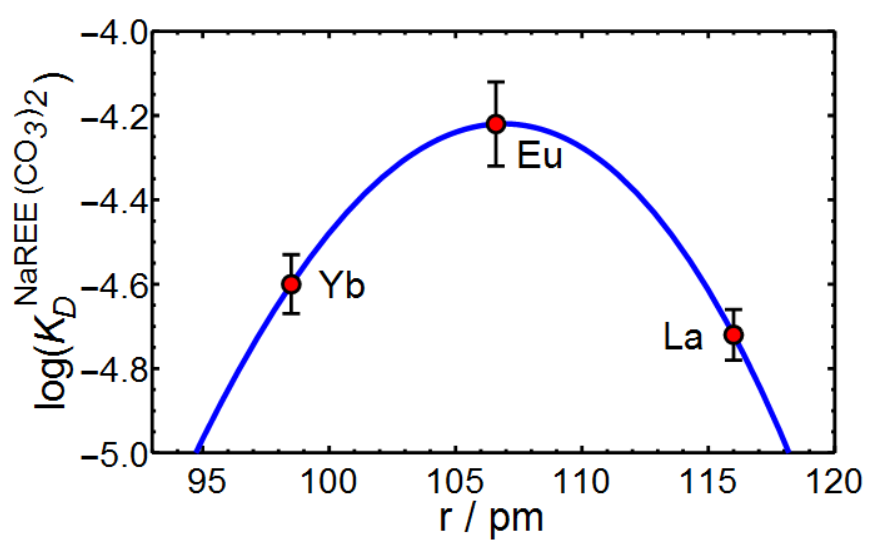

Figure 16

Relationship between the effective ionic radii $r$ of the REEs and the equilibrium distribution coefficient of the exchange mechanism involving $\mathrm{NaREE}\left(\mathrm{CO}_{3}\right)_{2}$. The red circles show experimental results from our experiments $(\mathrm{La}, \mathrm{Yb})$ and those of Lakshtanov and Stipp (2004) (Eu). The blue curve depicts the best fit to the lattice strain model of Blundy and Wood (1994). 


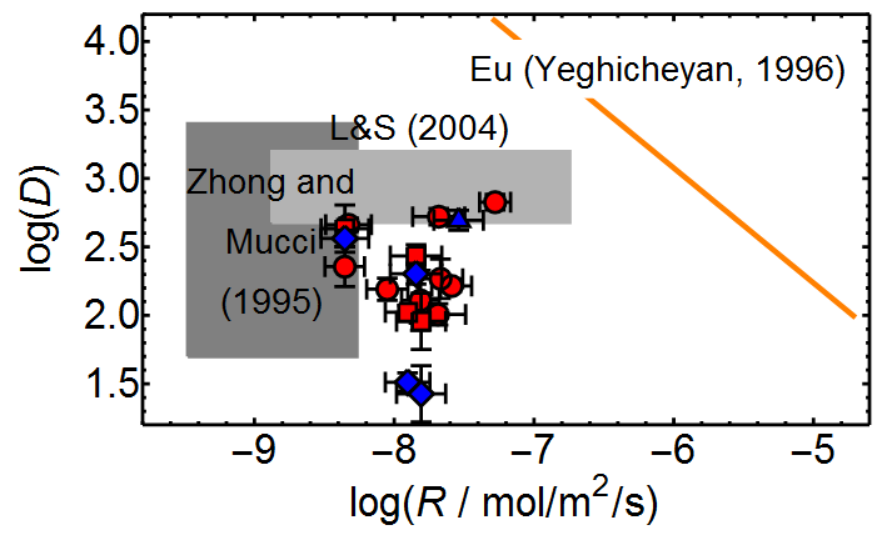

Figure 17

Relationship between the logarithm of the partition coefficient $D$ and the logarithmic calcite precipitation rate. The symbols represent our experimental data (see Fig. 4 for a legend). The dark and light grey areas show the range of values obtained by Zhong and Mucci (1995) and Lakshtanov and Stipp (2004), respectively, while the orange line shows a best fit equation determined by Yeghicheyan (1996) for the correlation they observed. 


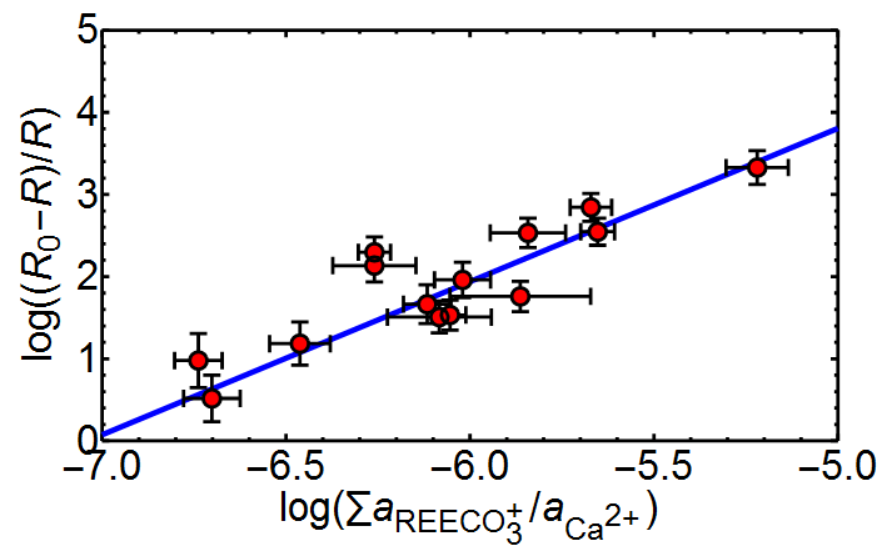

Figure 18

Plot illustrating the inhibitory effect of the REEs on calcite growth assuming a correlation between the $\mathrm{Ca}^{2+}$ surface site concentration and the growth rate, implying a linear relationship between the logarithms of $\left(R_{0}-R\right) / R$ and $\sum a_{\mathrm{REECO}_{3}^{+}} / a_{\mathrm{Ca}^{2+}}$. The blue line shows a best fit equation of this model. 

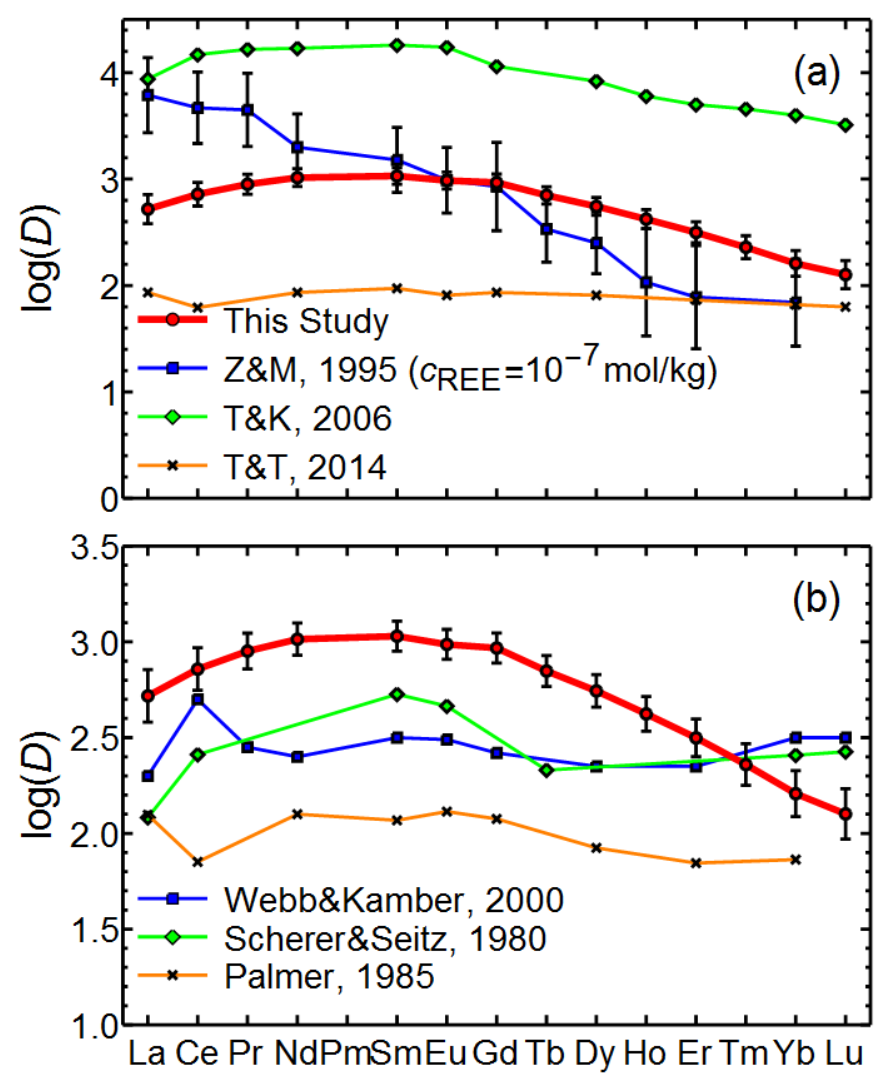

Figure 19

(a) Comparison of the partition coefficients $D$, calculated from experimental $K_{D}^{\mathrm{NaREE}\left(\mathrm{CO}_{3}\right)_{2}}$ and the best fit to the lattice strain model for a sea water matrix (Millero et al., 2008) to experimental data of Zhong and Mucci (1995), Tanaka and Kawabe (2006) and Toyama and Terakado (2014). (b) Comparison of the same calculated $D$ to partition coefficients calculated from natural samples: Reefal microbialities (Webb and Kamber, 2000), reefal Mg-calcites (Scherer and Seitz, 1980), and foraminifers (Palmer, 1985). 

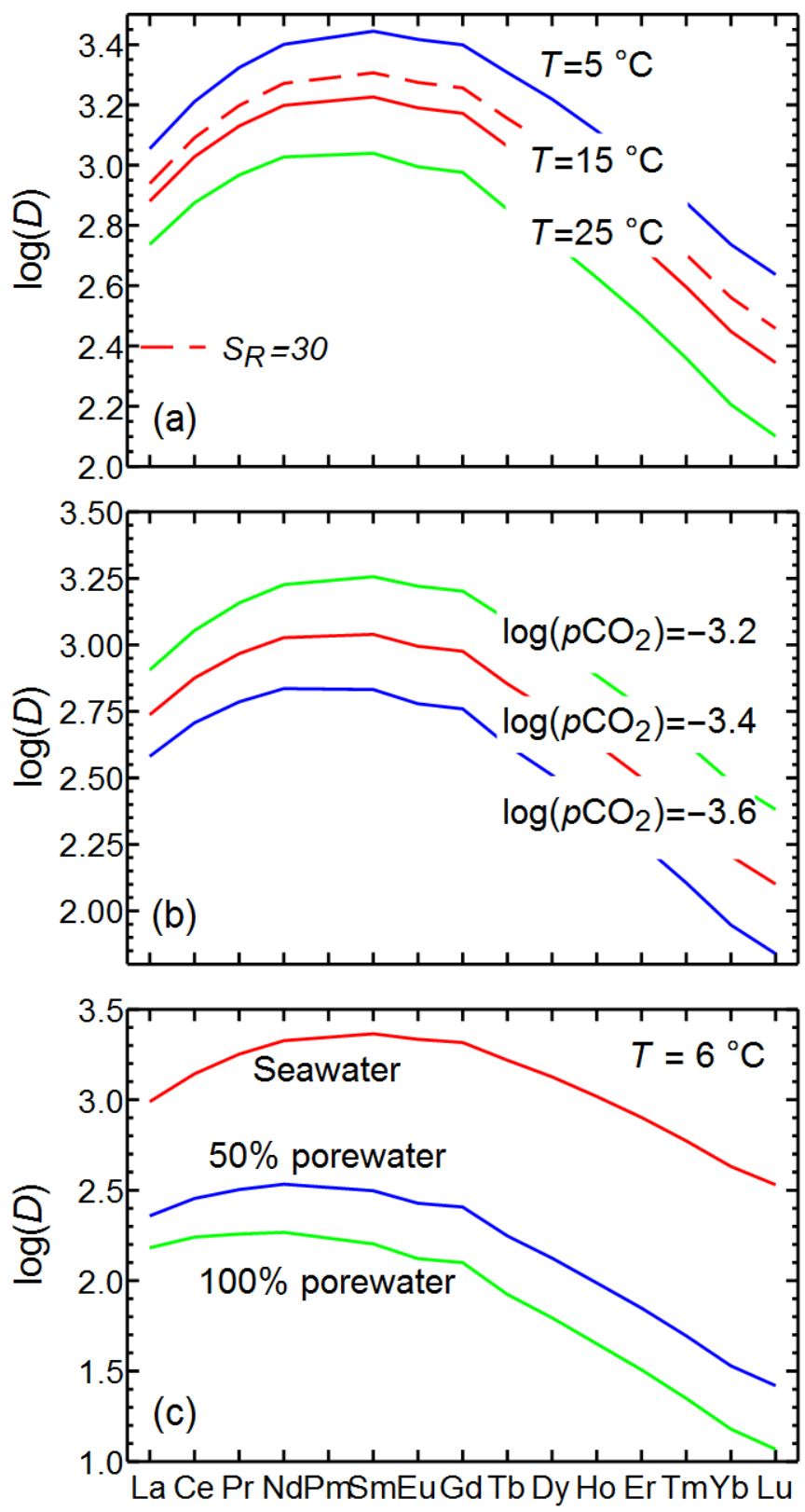

Figure 20

Partition coefficients calculated from experimental $K_{D}^{\mathrm{NaREE}\left(\mathrm{CO}_{3}\right)_{2}}$ and the best fit to the lattice strain model determined by us for variations in seawater compositions based on Millero et al. (2008), which is shown by the red curves. (a) shows the influence of the temperature (assuming negligible change in $K_{D}^{\mathrm{NaREE}\left(\mathrm{CO}_{3}\right)_{2}}$ and lattice strain over this temperature range) and reference salinity $\left(S_{R}\right)$ on the partitioning (at $\left.p H=8.2, p \mathrm{CO}_{2}=-3.4\right)$, while (b) illustrates the relationship between $p \mathrm{CO}_{2}$ and $D$ (at $T=25{ }^{\circ} \mathrm{C}, S_{R}=35$ and variable 
$p H)$ and (c) demonstrates the effect of the pore water chemistry, where the pure pore water is represented by the chemistry of the most extremely altered composition reported by Sholkovitz (1973). 
Table 4: Partition coefficients of REE between calcite and different aqueous solutions, calculated assuming incorporation of REEs into the solid as $\operatorname{NaREE}\left(\mathrm{CO}_{3}\right)_{2}$ using experimentally determined $K_{D}^{\mathrm{NaREE}\left(\mathrm{CO}_{3}\right)_{2}}$ and the best fit to the lattice strain model determined by us. The present day seawater composition is taken from Millero et al. (2008), the pore water composition is represented by the chemistry of the most extremely altered composition reported by Sholkovitz (1973), and $\mathrm{Mg}, \mathrm{Ca}$ and $\mathrm{SO}_{4}$ for cretaceous seawater are estimated from Horita et al. (2002). Columns $x_{i}$ show coefficients for the equation $D^{\mathrm{REE}}=$ $\left(x_{1} c_{\mathrm{Na}}\right) /\left(c_{\mathrm{Ca}}\left(0.45+10^{5} x_{2} a_{\mathrm{CO}_{3}{ }^{2-}}+10^{10} x_{3}\left(a_{\mathrm{CO}_{3}{ }^{2-}}\right)^{2}\right)\right)$ which allows the calculation of partition coefficients for seawater-like fluids based on an approximation of the model developed in this study.

\begin{tabular}{lrrrrrrr} 
& \multicolumn{3}{c}{$\log \left(D^{\mathrm{REE}}\right)$} & & & \multicolumn{3}{c}{ Coefficients for parameterization } \\
\cline { 2 - 5 } \cline { 6 - 8 } & $\begin{array}{l}\text { Present-day } \\
\text { seawater }\end{array}$ & Pore water & $\begin{array}{l}\text { Cretaceous } \\
\text { seawater }\end{array}$ & & $x_{1}$ & $x_{2}$ & $x_{3}$ \\
\hline $\mathrm{La}$ & $2.8 \pm 0.1$ & $2.4 \pm 0.1$ & $2.7 \pm 0.1$ & & $64 \pm 12$ & 3.08 & 1.15 \\
$\mathrm{Ce}$ & $2.99 \pm 0.08$ & $2.43 \pm 0.08$ & $2.96 \pm 0.08$ & & $175 \pm 25$ & 6.59 & 3.30 \\
$\mathrm{Pr}$ & $3.17 \pm 0.06$ & $2.53 \pm 0.06$ & $3.18 \pm 0.06$ & & $395 \pm 45$ & 9.75 & 6.90 \\
$\mathrm{Nd}$ & $3.38 \pm 0.05$ & $2.73 \pm 0.05$ & $3.41 \pm 0.05$ & & $745 \pm 68$ & 10.94 & 8.49 \\
$\mathrm{Sm}$ & $3.44 \pm 0.04$ & $2.71 \pm 0.04$ & $3.51 \pm 0.04$ & & $1480 \pm 107$ & 16.56 & 19.45 \\
$\mathrm{Eu}$ & $3.43 \pm 0.04$ & $2.69 \pm 0.04$ & $3.49 \pm 0.04$ & & $537 \pm 37$ & 5.51 & 7.78 \\
$\mathrm{Gd}$ & $3.55 \pm 0.04$ & $2.84 \pm 0.04$ & $3.59 \pm 0.04$ & & $556 \pm 38$ & 4.48 & 5.51 \\
$\mathrm{~Tb}$ & $3.35 \pm 0.04$ & $2.55 \pm 0.04$ & $3.45 \pm 0.04$ & & $523 \pm 37$ & 5.27 & 11.00 \\
$\mathrm{Dy}$ & $3.17 \pm 0.04$ & $2.36 \pm 0.04$ & $3.29 \pm 0.04$ & & $449 \pm 33$ & 6.63 & 14.84 \\
$\mathrm{Ho}$ & $3.02 \pm 0.05$ & $2.19 \pm 0.05$ & $3.16 \pm 0.05$ & & $360 \pm 29$ & 6.48 & 18.26 \\
$\mathrm{Er}$ & $2.81 \pm 0.05$ & $1.96 \pm 0.05$ & $2.97 \pm 0.05$ & & $275 \pm 24$ & 7.44 & 24.07 \\
$\mathrm{Tm}$ & $2.56 \pm 0.06$ & $1.69 \pm 0.06$ & $2.74 \pm 0.06$ & & $204 \pm 20$ & 8.74 & 33.99 \\
$\mathrm{Yb}$ & $2.37 \pm 0.06$ & $1.51 \pm 0.06$ & $2.53 \pm 0.06$ & & $150 \pm 16$ & 11.79 & 36.42 \\
$\mathrm{Lu}$ & $2.20 \pm 0.07$ & $1.32 \pm 0.07$ & $2.39 \pm 0.07$ & & $110 \pm 13$ & 10.27 & 42.80 \\
\hline
\end{tabular}

